\title{
KÉT SÍRKÁPOLNA A TÖRTÉNELMI VESZPRÉMI EGYHÁZMEGYÉBEN: BÉKÁS ÉS SZŐLŐSKISLAK - YBL MIKLÓS ÉS ÁGOSTON JÓZSEF MÚVEI
}

Egyforma lesz ott a szegény és a gazdag.

(Jób 3,19)

\section{Prológus: a Brüll-síremlék}

A Forster Központban 2015 őszén Bazsó Gábor kollégámmal kaptuk a feladatot, hogy a Kozma utcai neológ temetőben álló Brüll-mauzóleum rapid kutatását végezzük el a szükséges és nagyon is indokolt helyreállító munka részeként. A temető főbejáratának közelében, befelé haladva jobb kézre, a kerítésfal előtt található az antikizáló, cellafal nélküli in ante templom jellegü, kripta fölé emelt síremlék. (1. kép) A sarkon pillér, mellette sudarasodó, vájatolt ión oszloppár támasztja alá a homlokoldalon az összetett föpárkányt és a fríz felett az erős kiülésű, tripusszal koronázott timpanont. Az ión kima, tojásléc zárással keretezett képszéken a BRÜLL CSALÁD felirat olvasható. Az orommezőben aranymozaik háttér előtt kiterjesztett szárnyú madár, sas alakja látható, karmaival nyílhegy alakzatokban végződő, enyhén ívelt vonalvezetésű „pálca”-kötegen taposva. (2. kép) Közbevetőleg: a Brüll-síremlék közelében Heidelberg W. Lipót és családja szecessziós stílusú mauzóleumának kapuzatán bizonyosan sasmadár figura található; karmai között tölgyfaág, amit levele és makk termése igazol. Az Átváltozások költője szerint Jupiter szent fája a tölgy, „fegyvernöke” pedig a sas. ${ }^{1}$ A Brüllsírépítményt kőlapokkal héjalt nyeregtető fedi, ami utóbb bádogburkolatot kapott. A geiszonon az egykori oroszlánfejes vízköpők (oldalanként 3-3) rézrozsda színű furatai voltak megfigyelhetők. A mauzóleum eredetileg fémráccsal lezárható belsejébe ülő oroszlánszobor-párral szegélyezett ötfokú, pofafalas lépcső vezet.

A bejárattal szemközti falba rozettás keretezésü, aranymozaik borítású fülke mélyed, amely előtt posztamensre helyezett kőváza áll. A padozatban nyílik a kriptafedél. Az oldalfalak előtt oroszlánlábas kőpad fut L alakban. Az övpárkány fölött kétoldalt - erősen pusztuló állapotának ellenére is megítélhető - kvalitásos mozaikkép készült. A zsidó képtilalomnak megfelelően floreális, fehér és ró-

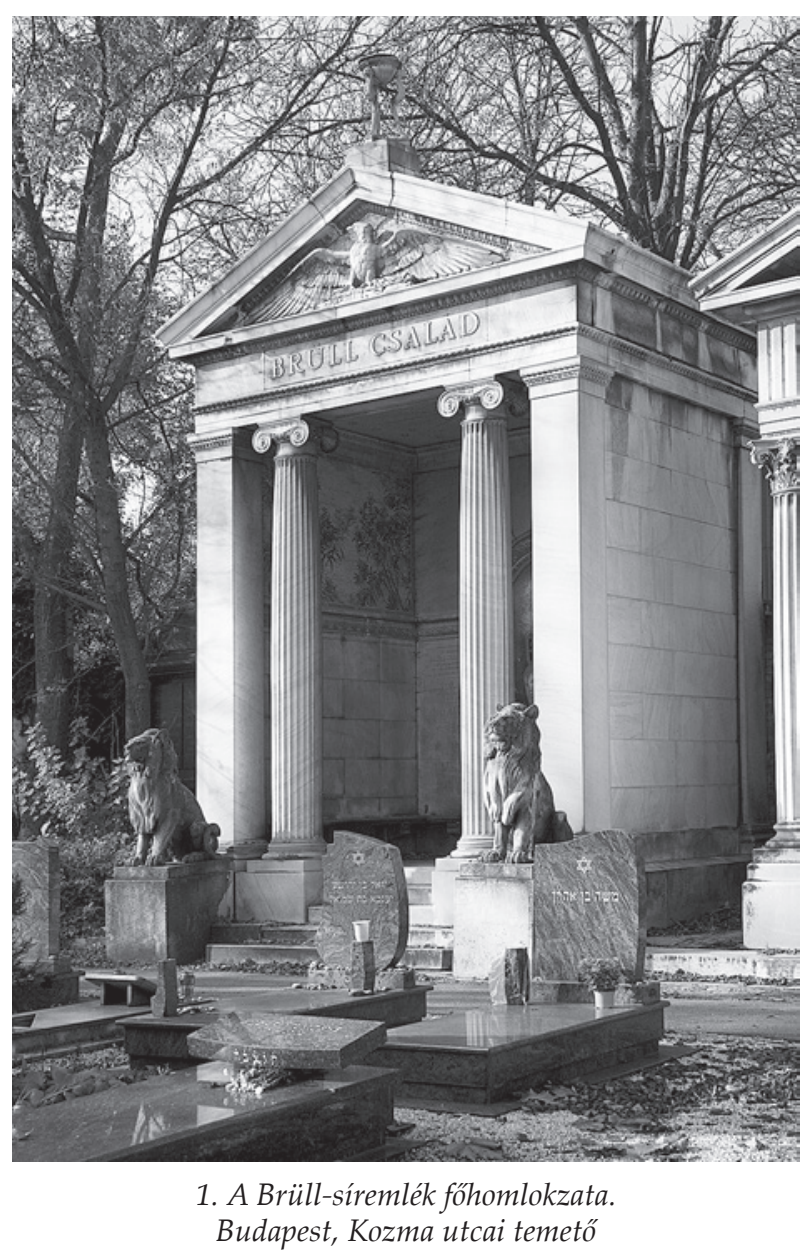




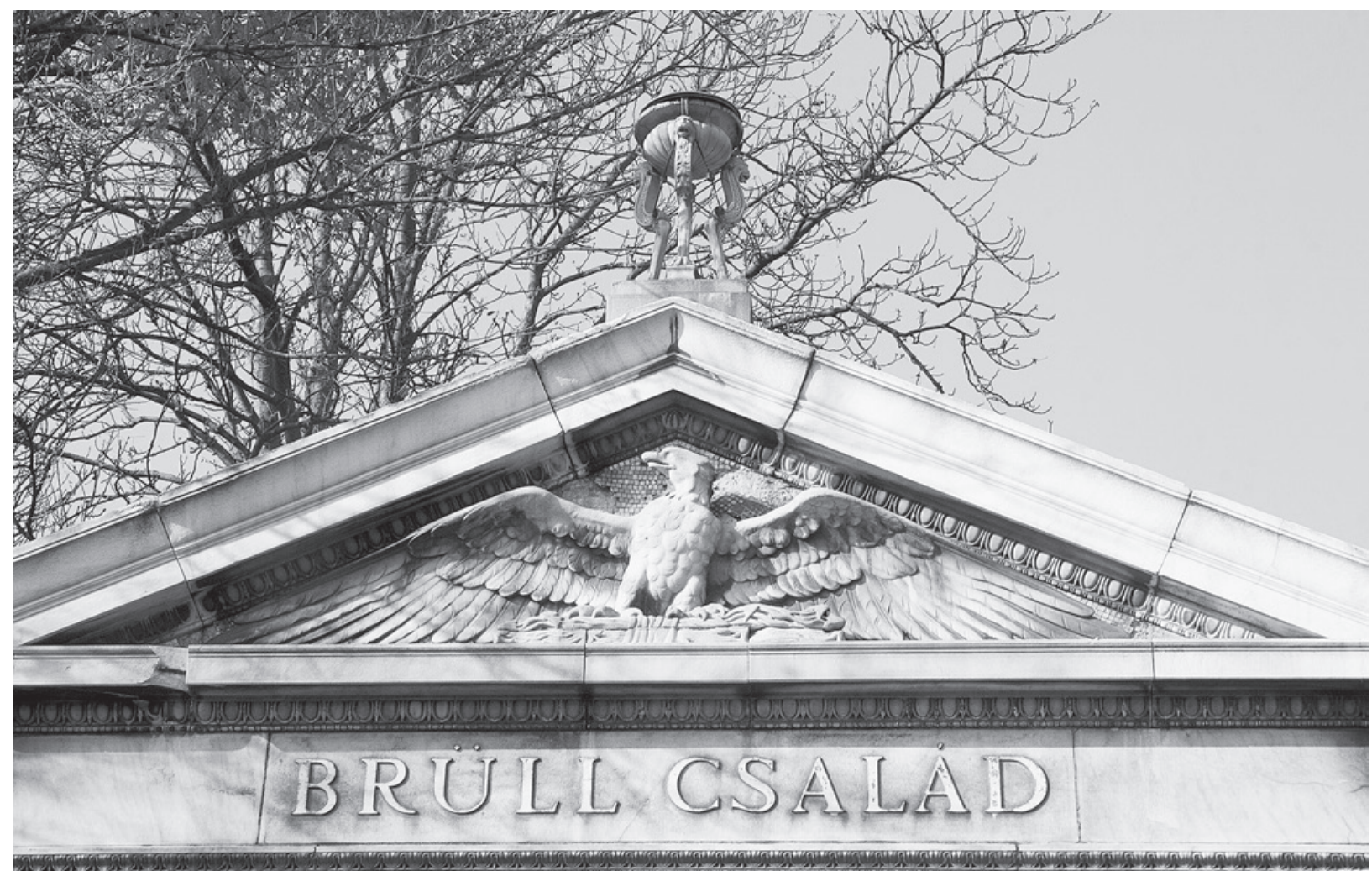

L2A.

2. A Brüll-síremlék timpanonja. Budapest, Kozma utcai temető

zsaszínű virágzó leanderágakat ábrázol; égszínkék háttér előtt jobb kézre, szemben vele kékkel átszőtt fehér alapon. (3-4. kép) A sík mennyezetet szintén mozaikkompozíció díszíti: kék alapon csillagok, centrumában napsugár koszorúzta Dávid-csillag. Az 1891-ben megnyílt temetőben Gerster Kálmán (1850-1927) tervei alapján épült a mauzóleum, a szobrászi részeket Stróbl Alajos (1856-1926) mintázta, miként ezt a jobb oldali oszlop talplemezébe (plinthosz) vésett felirat megörökítette. ${ }^{2}$

A Gerster Kálmán hagyatékában fennmaradt terven a mozaikkompozíció rajza is szerepel, valamint a timpanonba szerkesztett madáralak, de a karmaiban nem tart semmit. ${ }^{3}$ A hagyományosan Jeruzsálem irányába tájolt sírépítmény szimbolikája összetett, és többféle olvasata lehet - mivel nem ismerjük sem a megbízó, sem az alkotó szándékait. Tetőzet nélkül a felépítmény, a térforma kockához közelít négy és fél méter körüli befoglaló méreteivel. A Szentek Szentje, a Debir volt kocka alakú Salamon templomában (1Kir 6,21). Az újabb keletü gyakorlat és felfogás szerint a zsidó sírépítményt lezáró „hangsúlyozott timpanon... stilizált ohel sátor", ami azt jelzi, hogy alatta igaz ember, caddik nyugszik. A temető elnevezése lehet bét hajjim (az élet háza), vagy bét ha-olám (az örökkévalóság háza). ${ }^{4}$ Oroszlánok díszítették a király trónusát is
(1Kir 10,19; vö. Ter 49,9; Szám 23,24). Az urna mákgubókkal díszített, ami ismert antikvitásbeli jelképe az álomnak, elmúlásnak. A háttér aranymozaikja (az anyag itáliai, Salviati és Jesurum-gyártmány lehet) előrevetíti a megdicsőülést. Az övpárkány fölött eredetileg a cella mindhárom oldalát mozaikkép borította, amely az Édenkertre emlékeztethet.

A Brüll Ármin és Zsigmond (†1899, mindketten) egyesítendő sírboltja - a kerítésfal előtt egy dongaboltozatos „kriptafolyosó" fut - fölé emelendő síremlékre 1901. március 28-án 10794/1901-III. (77257726/2b régi hrsz.) számon kapott építési engedélyt Gerster Kálmán és a felelős építőmester. Az engedélyezési terv tulajdonképpen egyezik a Gersterhagyatékban őrzöttel (MNL OL), de ez lavírozott, színezett és a sírboltegyesítés vázrajzát is feltünteti. A díszítő részletek vonatkozásában szintén egybevágnak és megfelelnek a megvalósult formának, de a sas nem tart semmit a karmai között ezen a kivitelezést szolgáló tervlapon sem. (5. kép)

A X. kerület elöljárósága 1902. december 9-én küldte be a Székesfővárosnak az említett tervlapot és az iratokat azzal, hogy az „építkezés szakszerü befejezést nyert." ${ }^{5}$ A következő évben az Épító Ipar két képpel és egy alaprajzi ábrával illusztrálva bemutatta a domonyi Brüll család részére 41800 koronáért ${ }^{6}$ épített mauzóleumot, melyet görög re- 


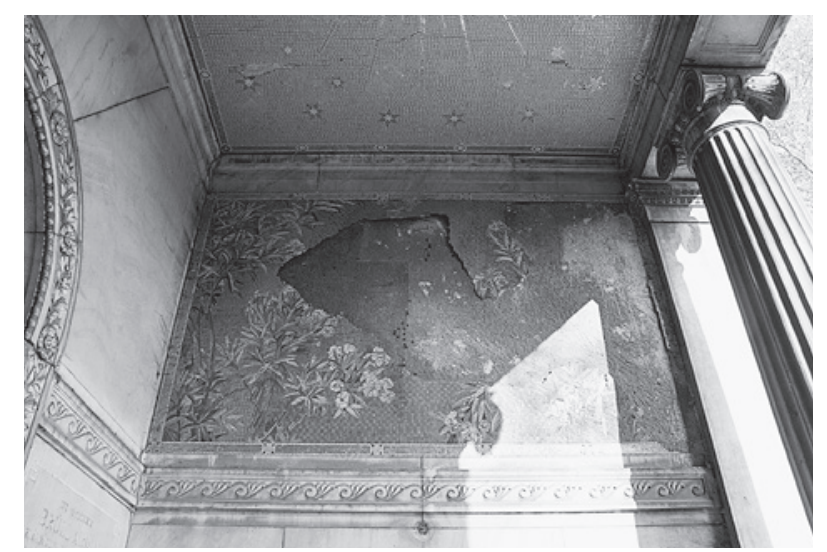

3. Mozaikkép virágos leanderágakkal a Brüll-síremléken. Budapest, Kozma utcai temető

neszánsz stílusban tervezett meg építésze. A Stróbl által mintázott oroszlánpár anyaga tiroli laázi márvány. Ruszkicai márvány az épület burkolóanyaga és tagozatai (utóbbi „némi aranyozással”, például az oszlopfökön), valamint a sas is, amely egybe lett faragva a timpanon megfelelő építészeti elemével. A kőfaragómunka mestere a közlés szerint Král Gyula, a díszítő szobrászmunkáé Vögerl Alajos, a feliratok betűvésnöke pedig Blum Lajos volt. A bronzkapu, a lámpák és a tripusz Vandrák László mühelyében készültek. A közölt fénykép tanúsága szerint a bronzkapu a felvétel időpontjában még nem volt kész, a bejárattal szemközti falon a mozaikkép mára elpusztult harmadik eleme azonban felismerhető; kartonjukat Lohr Ferenc készítette. ${ }^{7}$

A Brüll családi sírbolt timpanonjában az aranymozaik háttér előtt megjelenő madárfigura a szimbólumrendszer „csúcsa”. Főnix (a történetet hellenista zsidó szerzők is magyarázták ${ }^{8}$ ) aligha lehet, mert az a faragványelem, amelyen a madár áll, nem azonosítható venyigeköteggel a "fészek” jelzésszerü ábrázolásaként. Inkább villámcsóva lehet a Zeuszt, azaz Jupitert (Fulguralis) megszemélyesítő sas karmában; a sas az erő, a megújulás, a égboltozat felé emelkedés szimbóluma. ${ }^{9}$ Az emlék restaurálása során az is láthatóvá vált, hogy a villámköteg felső része egybe lett fogva a sasfigurával. Ha nem is maga Stróbl vésője faragta ki a kompozíciót, akkor sem képzelhető el, hogy a kőfaragó mester saját ötlete lett volna a Jupitert jelző motívum. Az antik hagyományból értelmezve pedig az Édenkertet megjelenítő mozaikkompozíció az Elysiumra, az elköltözés mezejére való utalás. A Biblia keretei között maradva (bár a sas tisztátalan állatnak számított) Izajás próféciájának értelmében: „,.. akik az Úrban bíznak, erejök megújul, szárnyra kelnek, mint a saskeselyűk, futnak és nem lankadnak meg..." $(40,31)$, de idézhető a 103. (102.) zsoltár 5. verse is: „Áldjad én lelkem az Urat... aki jóval tölti be a te

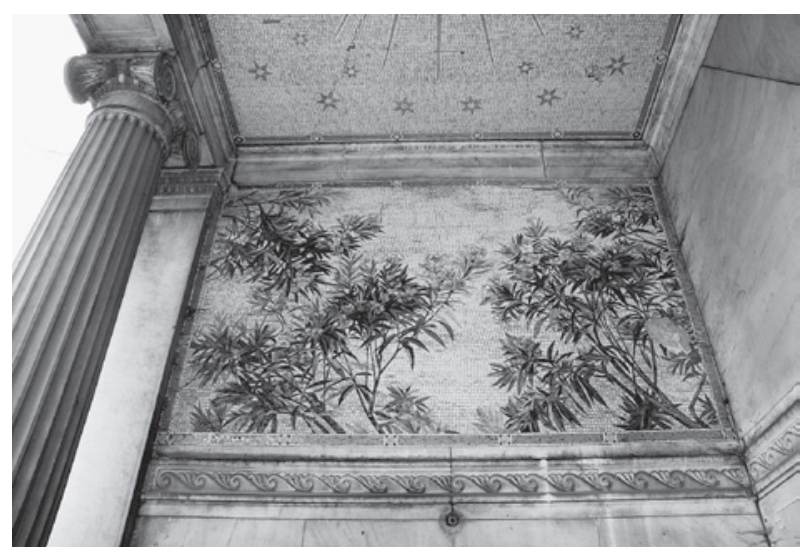

4. Mozaikkép virágos leanderágakkal a Brüll-síremléken. Budapest, Kozma utcai temetó

ékességedet és megújul a te ifjúságod, mint a sasé" (Károli Gáspár fordítása) ${ }^{10} \mathrm{Az}$ Örökkévaló feltámadásra vonatkozó ígéretének olvashatjuk a sorokat az Ószövetség talaján állva is. Program hiányában (a megbízó és a múvészek között) egyértelmű „olvasat" nincs, a villámköteg pedig faktum. Óbudán a Lajos utcai klasszicista zsinagógában (1820-21) a templomtér közepén a gazdag architektonikus kialakítású empire ízlésű bima négy sarkán egy-egy

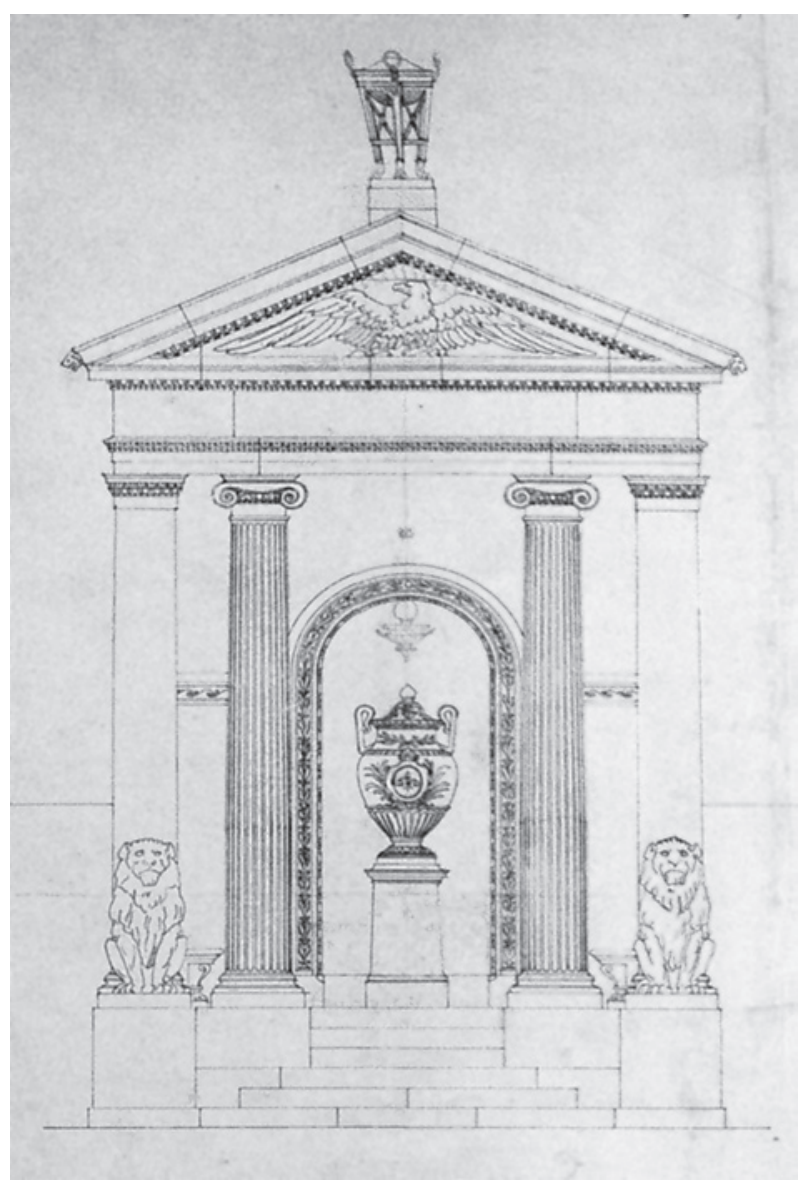

5. A Brüll-sremlék fóhomlokzatának tervrajza 
obeliszk emelkedett, mindegyik tetején kiterjesztett szárnyú aranyozott sassal. ${ }^{11}$ A Brüll-síremléken a mozaik, a murália igényelte a legsürgetőbb beavatkozást, állagmegóvást. ${ }^{12}$

\section{Békás, Békássy-Hollán-sírkápolna}

A Mưvészet folyóirat 1903-ban az „Új emlékmüvek" című rovatban az alábbi ismertetést tette közzé: „November elsején leplezték le a Timapusztán Hollán Ernő altábornagy síremlékét, amelyet a Magyar Mérnök- és Építész-Egylet állíttatott. Az emlék a sírkápolna jobb falát díszíti, tervét Czigler Győző készítette, a domborművű bronz képmást Szécsi Antal mintázta, a freskókat Lotz Károly kartónjai nyomán Kölber Dezső festette."13 Timapuszta, és ezért a leszármazottak tulajdonában álló sírkápolna is ma Békás községhez tartozik (hrsz.: 100). Az emlékavatásról a Magyar Mérnök- és Építész-Egylet Heti Értesítője szintén beszámolt: „Hollán Ernőnek, nagy nevű alapító elnökünknek egyesületünk díszes síremléket készíttetett a Tima-pusztán lévő, Ybl

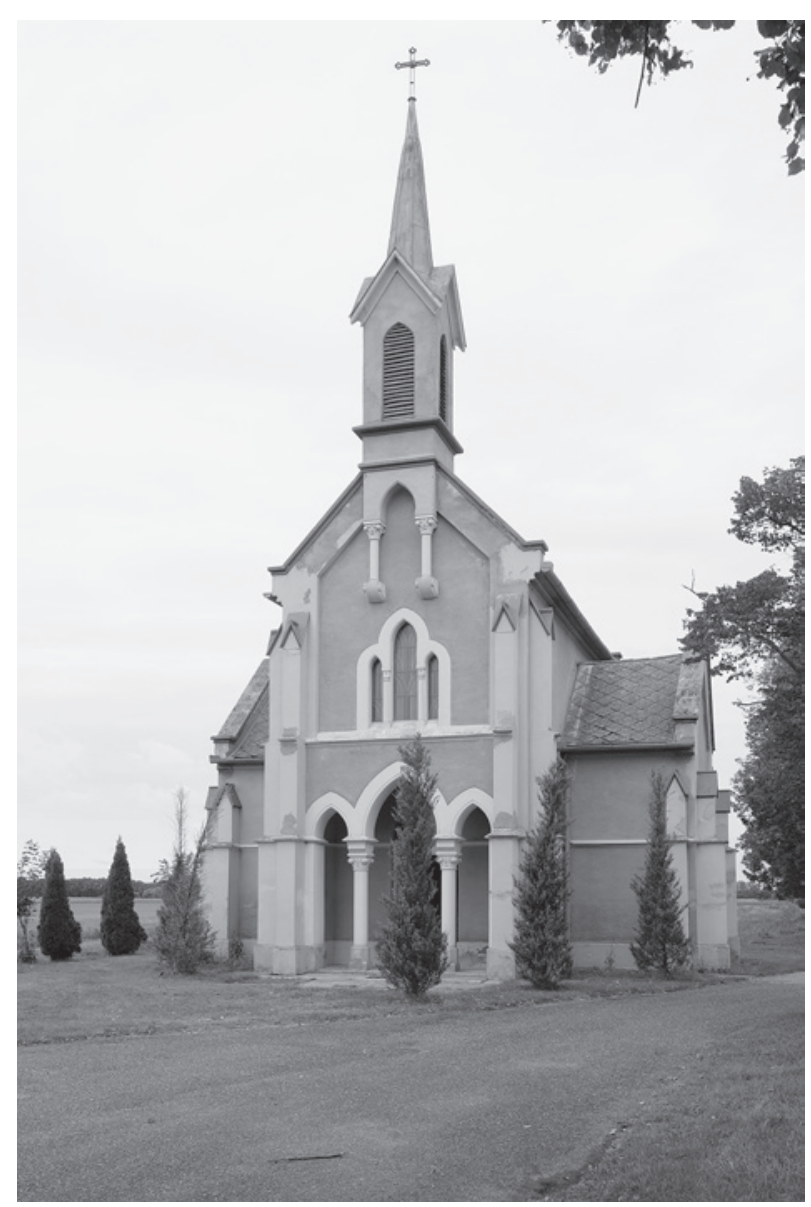

6. A Békássy-Hollán-sírkápolna fóhomlokzata. Békás mesterünktől származó családi sírboltban”. Az elnökség október 31-én adta át az emléket az özvegynek. A családi jellegü „szerény” ünnepen a Magyar Tudományos Akadémia is képviseltette magát. Leírást is közreadtak a műről: az „emlék középpontját a nagy halottnak dombormívú mellképe, tábornagyi egyenruhában alkotja..., melynek két oldalán egy-egy festett nemtő áll őrt, egyik a mérnök tárcsás lécét, a másik a katona pallosát tartja a kezében". Az alkotók felsorolása egyezik a Múvészetben közöltekkel. Az Értesítő a Hollán-Sírkápolna (sic) homlokzati fotóját - tervezte Ybl Miklós, erősíti meg a képaláírás -, a síremlék fényképét és a kápolna alaprajzát is közölte. ${ }^{14}$ Hollán Ernőt, a Szombathelyen 1824. január 13-án született és Bécsben hadmérnöki akadémiát végzett tisztet Kossuth Lajos őrnaggyá, hadmérnöki főökké nevezte ki. Tagja volt a kiegyezést előkészítő bizottságnak, valamint az ország vasúthálózatának kiépítésében szerzett érdemeket. Haláláról az Egylet Ertesítőjének rendkívüli száma adott hírt: „Egyesületünk elnöke... [1900.] május hó 29-ik napjának első órájában költözött el közülünk." Az Egylet május 30-án Budapesten du. 4 órakor tartandó gyászszertartáson testületileg jelenik meg, és az

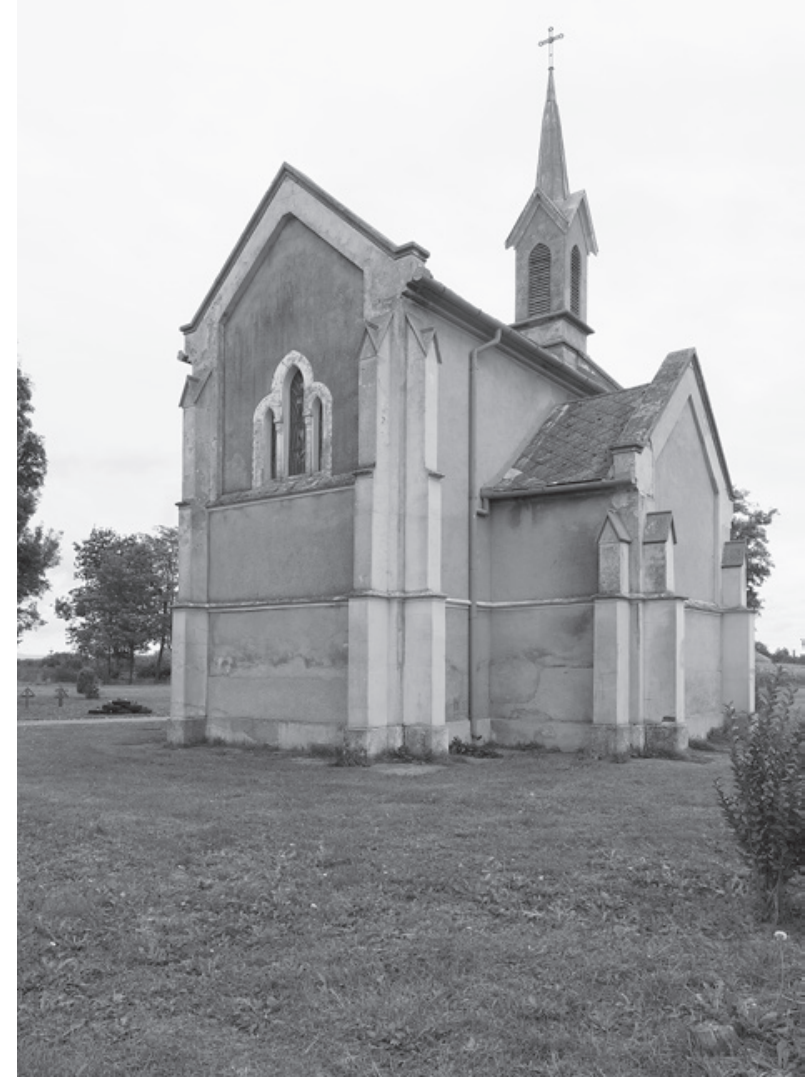

7. A Békássy-Hollán-sírkápolna a szentély felól. Békás 


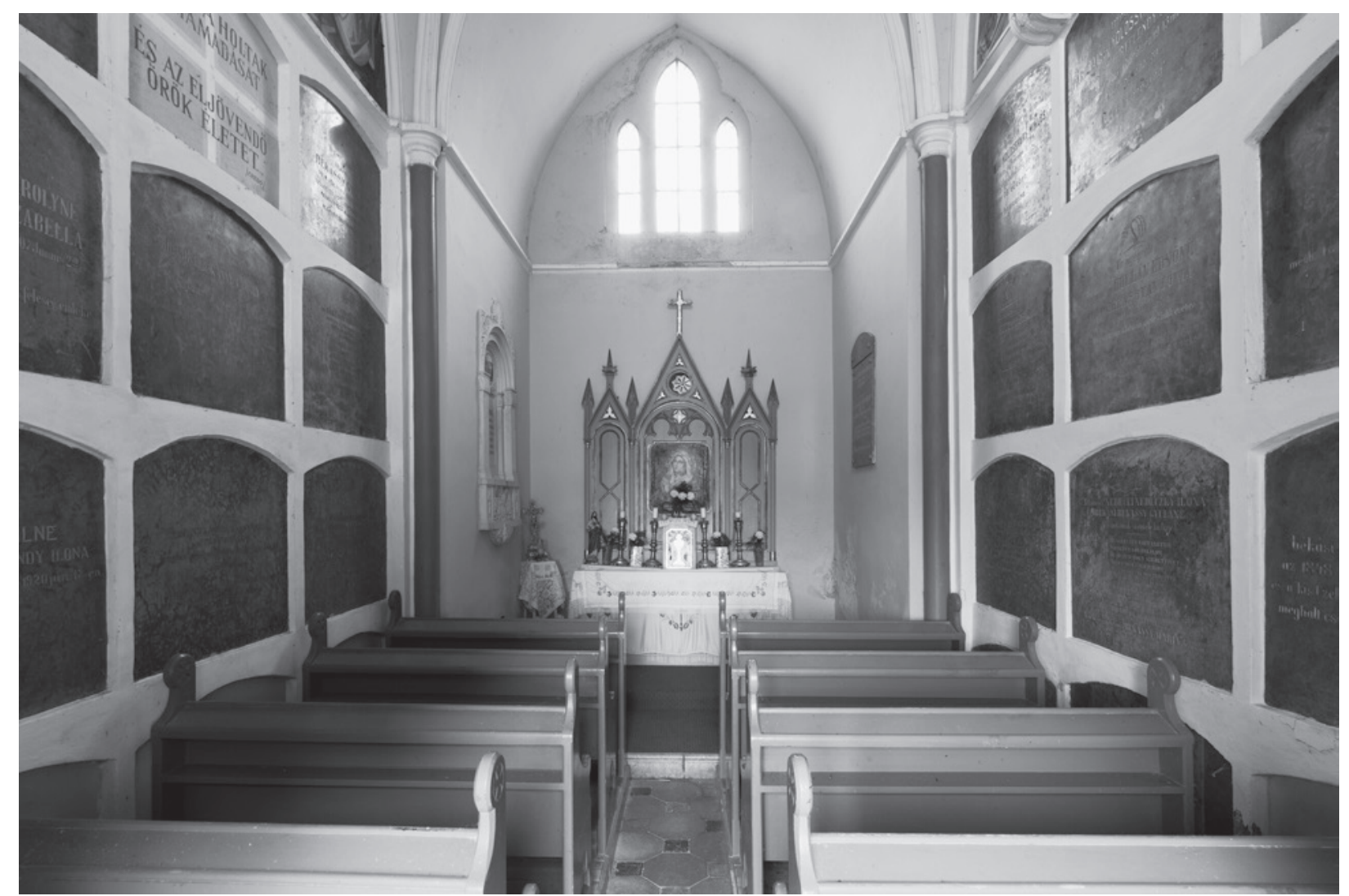

8. A Békássy-Hollán-sírkápolna belső tere az oltár felé. Békás

elhunytnak az „egyesületi helyiségben (IV. Ujvilág u. 2. II. em.) lévő arczképét egy éven át gyászfátyollal borítja... a Békáson rendezendő végtisztességtételen küldöttségileg vesz részt" ${ }^{\prime 15}$

A Hollán-emléket és a „sírboltokat” magába foglaló kisméretü, közel szabályos görögkereszt alaprajzú (cca. $8 \times 7,5 \mathrm{~m}$ ) kápolna csúcsíves, gótizáló formákkal épült. A háromnyílású portikusz fölött hármas ablak töri át az oromzatos homlokzatot (a középső tengelyek záradéka megemelt), melyet aediculás alépítménnyel megtámasztott harangtornyocska koronáz. (6-7. kép) A központi teret négy süvegből álló bordás keresztboltozat fedi. A keresztház falazatában (tömegében) kerültek kialakításra három sorban a 12-12 koporsót befogadó fülkék (Hollán Ernő koporsóját a jobb oldali falazatban, a középső sor első fülkéjében helyezték el). (8. kép) Czigler Győző (1850-1905) a klasszikus aediculás szoborfülke kialakításának módjában igazodott a kápolna kései romantikus-historizáló stílusához. A Szécsi Antal (1856-1904) mintázta bronzképmás a „Gladenbeck H. féle Múérczöntöde Rész-Társ Budapest"-i mühelyében készült. (9. kép) A bal oldali falon az emlékkel átellenben egy Krisztus sírbatétele-falkép látható. ${ }^{16}$ Békássy Ernő huszárkapitány (†1914. VIII. 23., Medvedovce) epitáfiumát Kisfaludi Strobl Zsigmond faragta. A hősi

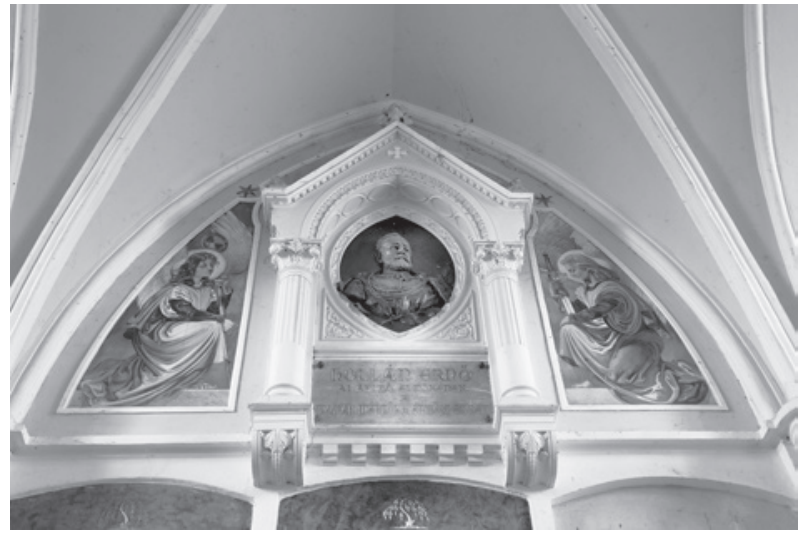

9. Hollán Ernő síremléke a Békássy-Hollán-sírkápolnában. Békás

halál jelenetét megörökítő dombormü előképe az Egerben felállított Végvári harcosok szoborkompozíciónak (1967). ${ }^{17}$ (10. kép)

Emléktábla őrzi a kápolnában id. és ifj. Hollán Sándor emlékezetét is (utóbbi a MÁV igazgatója volt), akik a vörös terror áldozataivá váltak a Lánchídon 1919. április 22-én.

Hollán Ernő, a „magyar technikusok legnagyobb alakja" 1860-ban biztosan kapcsolatban állt Ybl Miklóssal, Széchenyi István nagycenki (Czenk) templomának építése kapcsán. ${ }^{18} \mathrm{~A}$ Mérnök Egy- 


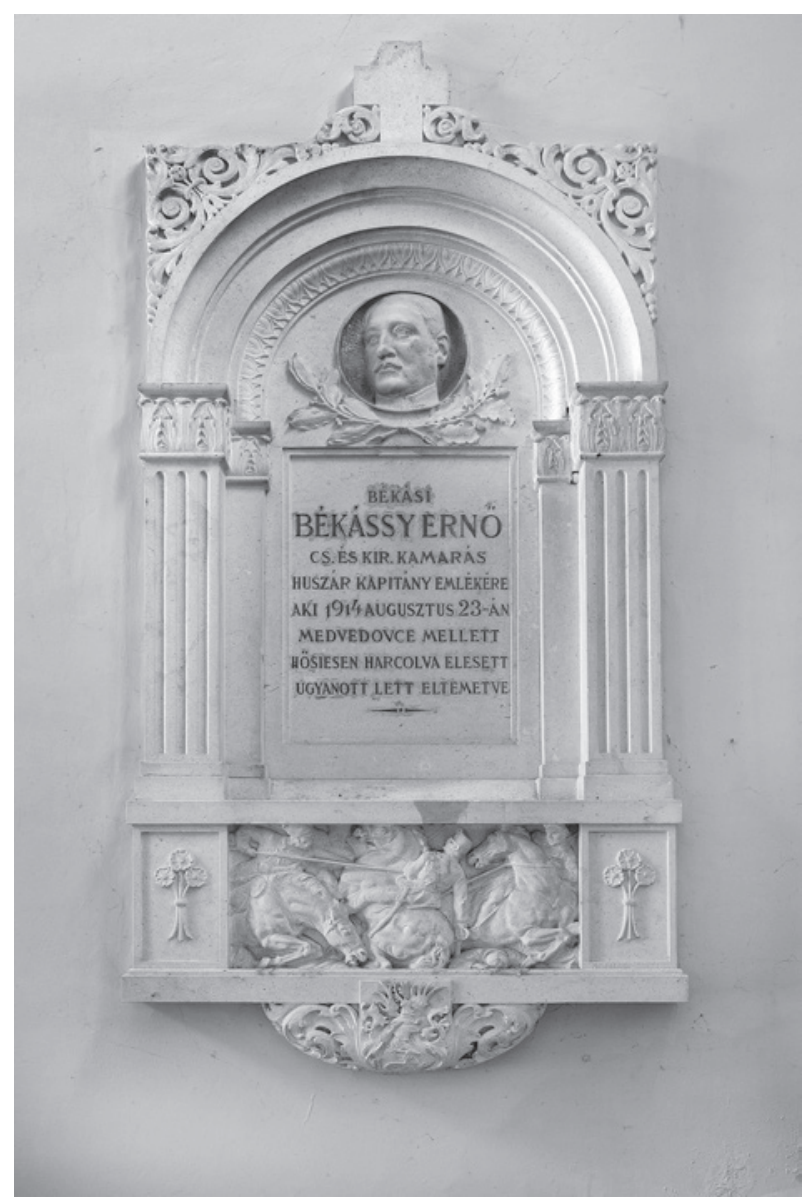

10. Békássy Ernő síremléke a Békássy-Hollán-sírkápolnában. Békás

let építész szakosztálya nevében 1882 . december 5-én, Ybl működésének 50. évfordulóját ünnepelve Hollán üdvözölte a mestert, és ő lett később az Yblszoborállító bizottság elnöke. ${ }^{19}$

A kápolna datálása fontos eleme az œuvre-ben való elhelyezésnek. Békáson 1869. szeptember 12én Szpránszky Ferenc nyárádi plébános és a szintén nyárádi (olvashatatlan) János tanító mint tanúk előtt a Békássy család számos tagja, közöttük Hollán Ernőné, szül. Békássy Antónia az alábbi nyilatkozatot tette: „Alulírt család ezennel egyenként és egyetemesen kötelezzük magunkat, miszerint azon sírbolt-kápolnát, melyet Isten segítségével 1869. évben részint Isten dicsőségére s mi magunk leendő csendes nyughelyéül építtettünk, s ugyanazon évi szept. 12-én Mária Szentneve tiszteletére felszenteltettünk - mind magunk mindenkor a legjobb karban fenntartjuk, mind utódaink által fenntartani fogjuk." ${ }^{20}$ A nyárádi plébános (Békás Nyárád filiája volt) 1869. május 10-én tájékoztatta püspökét, Ranolder Jánost, hogy a „tek. Békássi (sic) család kriptát, mely egyúttal kápolna is leendne, melyben misézni lehetne, szándékozik építeni... a kriptakápolnának minden- korra jó karban fönntartására (kiemelés P. E.) magát kötelezi" ${ }^{21}$

Az egyházi hatóság számára a jó karbantartási kötelezettség vállalása volt a fontos, és nem a tervező személye vagy az architektúra minősége, hogy a „vérnélküli áldozatja a Mindenhatónak bemutatható legyen" mindenkor és méltón. Szpránszky plébános augusztus 18-án (1869) kérvényezte - tehát az építkezés befejeződött vagy befejezés közeli állapotban volt -, hogy a „Békássy család kívánata miért, nem tudom, hogy én szenteljem fel az általa épített szép góth alakú sírkápolnát Mária neve napján". S egyben jelezte azt is, hogy a fenntartásáról szóló okirat ezen alkalomból készül el, mert az egymástól távol élő család tagjai ekkor gyúlnek össze. A kápolna megáldásának (!) engedélye megadatott a számára. ${ }^{22}$

$\mathrm{Az}$ Ybl-irodalom eleddig (tudomásunk szerint) nem tartotta számon a mester alkotásai között a Békássy-Hollán-sírkápolnát. ${ }^{23}$ Ney Béla közremüködését fel lehet vetni, de igazolni szükséges. ${ }^{24}$ Ybl Miklós (1814-1891) funerális alkotásai között a Békáson álló kápolna múépítészeti szempontból ugyan aligha a legkiemelkedőbb, de az építész és az építtető Hollán családnak a magyar történelemben és szakmatörténetben játszott szerepe okán is jogosult a nyilvántartott műemléki érték státuszra.

\section{Szőlőskislak, Ágoston-Kacskovics-sírkápolna}

2016 őszén, elpusztult műemléki értékek jegyzékből való törlésével kapcsolatos helyszíni bejárás alkalmából szereztünk tudomást a kislaki romkápolnáról. A temető szélén, a bozótosban a növényzet úgy belepte az építményt, hogy csak a célzott keresés vezetett a nyomára. ${ }^{25} \mathrm{~A}$ vörös színre hangolt, pódiumon álló kőlábazatos kápolna északnyugatról nyíló terébe két-két dór oszloppal szegélyezett, apró portikuszon át vezet az út. (11. kép) Az oszlopok szabályszerűen lábazat nélküliek, a tégla magot egykor vakolatból húzott vájatolás, kannelúra borította. A timpanont alátámasztó abakusz, a négy darab fejlemez szinte egy-egy táblát alkot a széleken. A kapuszárnyait vesztett, szegmensíves záródású bejárat vörösmészkő szemöldök-kőtáblájába (supraport) szépen metszett kapitális antikva betűkből álló felirat elárulja az építmény rendeltetését és célját: KIS JÓKAI ÁGOSTON JÓZSEF ÉS NEJE KACSKOVICS HERMIN / SZERETETT ÉS FELEJTHETETLEN ATYJUK / KACSKOVICS IGNÁCZ / EMLÉKÉRE. (12. kép) A nevezett földbirtokos 1843ban a vármegye főszolgabírája volt, az 1865-ik évi választásokon Lengyeltótiban országgyülési képviselői mandátumot szerzett, és ugyanazon évben 


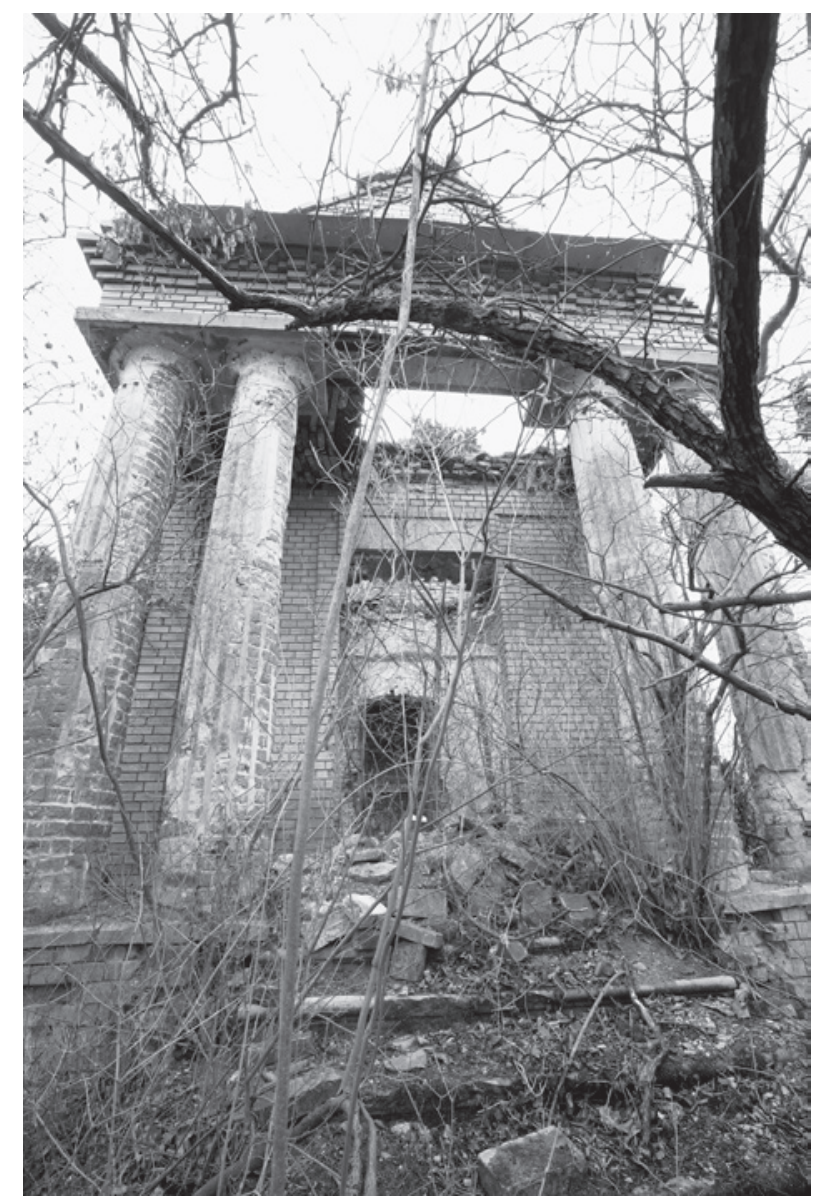

11. Az Ágoston-Kacskovics-sírkápolna föhomlokzata. Szőlőskislak

kastélyt is építtetett Gyugy községben. ${ }^{26}$ Elhunyt 1876-ban.

A négyzetes kápolnatér oldalfalát egy-egy nagyméretü, félköríves záródású ablak nyitja meg a lábazati parapetzónától indulva, alatta tengelyben a kriptabevilágító ablakpár helyezkedik el. Kelet felé egy összetett térrész maradéka tárul fel: a menynyezetét (boltozatát?) vesztett kriptalejáró, amely felett vízszintes osztófödém áll, és boltozott a kifelé nyílás nélküli tér lezárása. A vakolt, kékre színezett kápolnabelsőn téglapárkány maradéka fut körbe, a sarkokban az ívháromszög kialakítású csegelyek csehsüveg boltozatot támasztottak alá. (13. kép)

A kriptába a kápolna kubusából erőteljesen kilépő, hasáb alakú „,apszis” alatt jutunk le. (14. kép) A kripta lapos donga boltozású (kétszakaszos a rézsűs bevilágítópár miatt), a szakaszválasztó hevederszerű megoldású. A nyugati falban három sorban tizenkét koporsófülke van. (15 kép) A beomlott kripta (pince) gádor felett állhatott az oltár. A lejáró szemöldökkövében körív mentén vezetett felirat - KEGYELET SZERETETÉRT - fogja közre az egyesített Ágoston-Kacskovics családi címert. ${ }^{27}$ (16. kép)

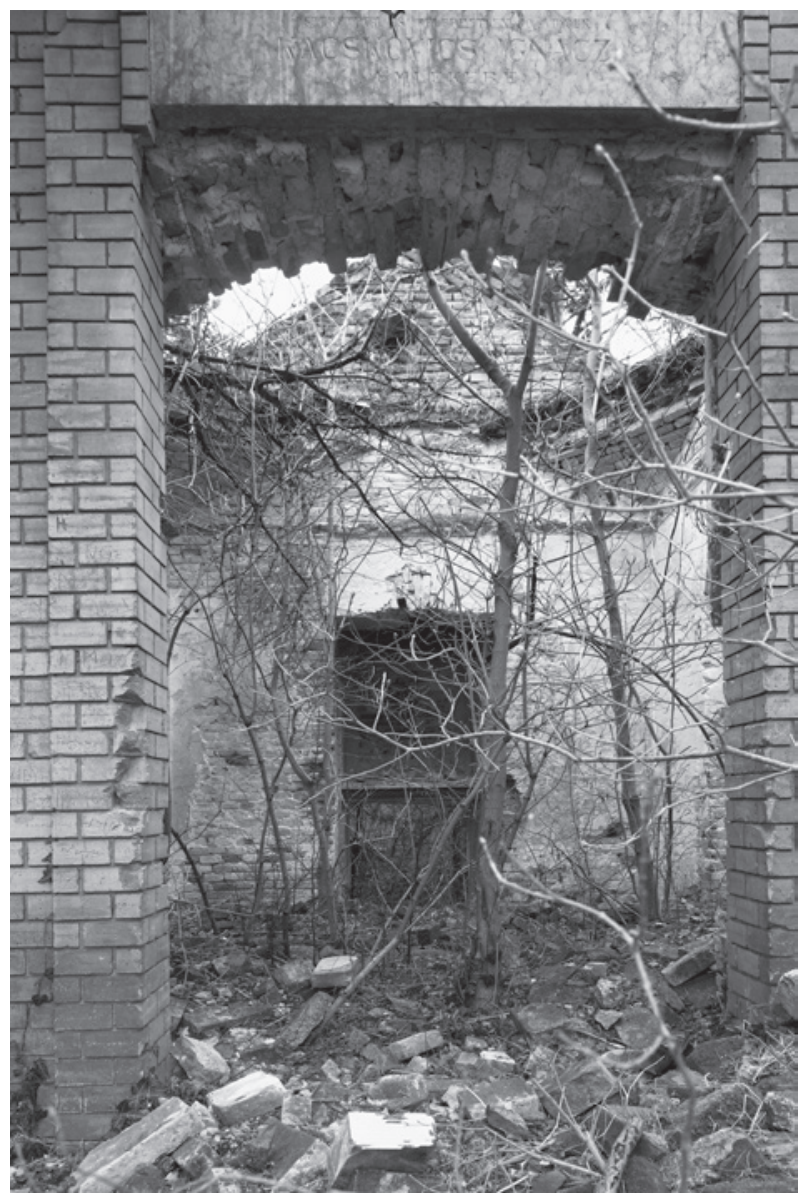

12. Az Ágoston-Kacskovics-sírkápolna romos belseje. Szőlőskislak

A kápolna tömegét egy fotó-képeslap tanúsága szerint - felirata (kézírással): Családi Sír-kápolnánk. 1901 [?] 7. - nyeregtető fedte, gerincének két végén kereszt magasodott. ${ }^{28} \mathrm{Az}$ alacsonyabb apszis-kripta lejáró tetőzete kérdéses, de logikusan (kontyolt) nyeregtető lehetett.

A kápolna megjelenésének hatásosságát a vöröses, sajtolt, idom- vagy dísztégla burkolat szolgálja, ez keretezi a nyílásokat, faltükröket, sarkokat, ebből épült a geometrikus konzolok között a fogazatos fópárkányzat is. Nem volt nehéz (sajnos) a törmelékben ép darabokat is találni, ráadásul bélyegeset: mélyített kör mezőben domborított LNJ betücsoport. ${ }^{29} \mathrm{Az}$ LNJ betüjeles tégla Kőbányára mutat, (ifj.) Lechner Nepomuk János téglagyárában készült a burkolóanyag. ${ }^{30}$ Lechner Ödön (18451914) kései önéletrajzában így írt: „atyám örökösödés útján egy téglagyár birtokába jutott... annak igazgatásával foglalkozott. Ebben a gyárban már korai ifjúságomban megtanultam bánni az agyaggal s megszerettem a kerámia különböző technikáit. Mert a gyárban nem csupán közönséges téglákat gyártottak, hanem finomabb kerámiákat is, többek 


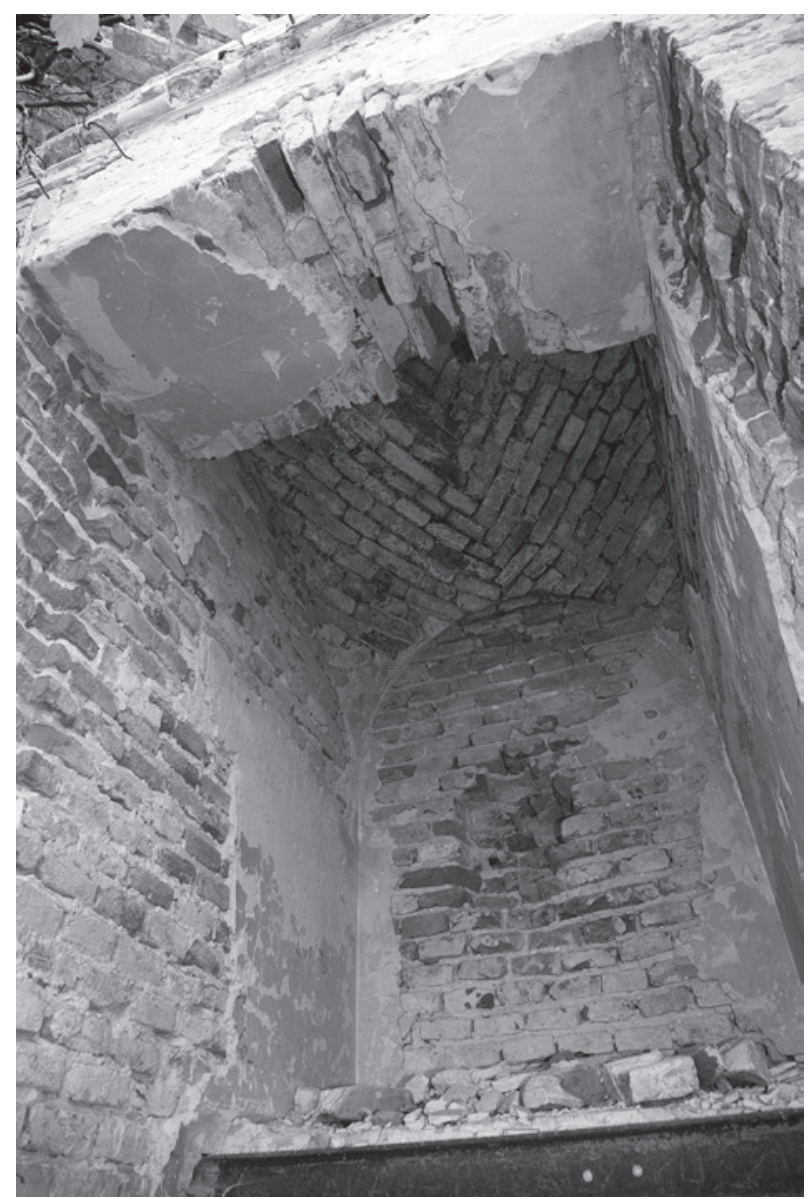

13. Boltozat részlete (az oltár mögött)

az Ágoston-Kacskovics-sírkápolnában. Szólőskislak

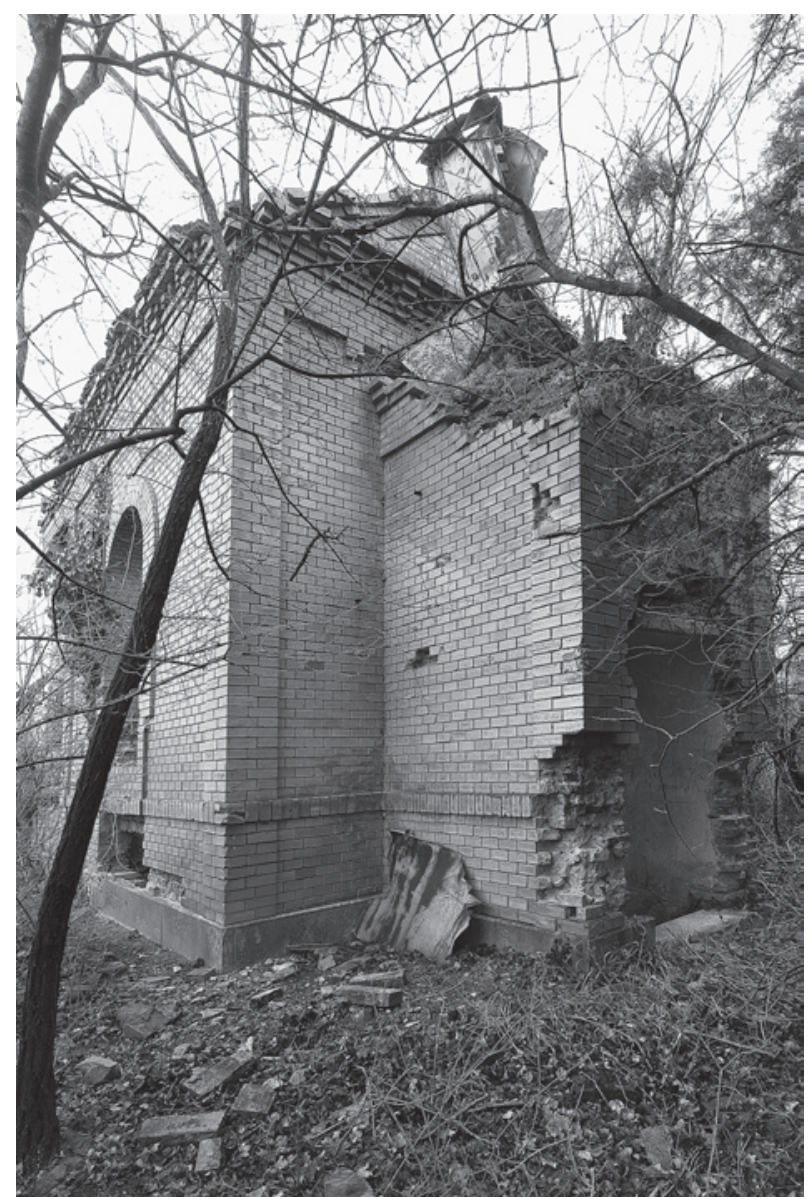

14. Az Ágoston-Kacskovics-sírkápolna a szentély felöl. Szőlőskislak

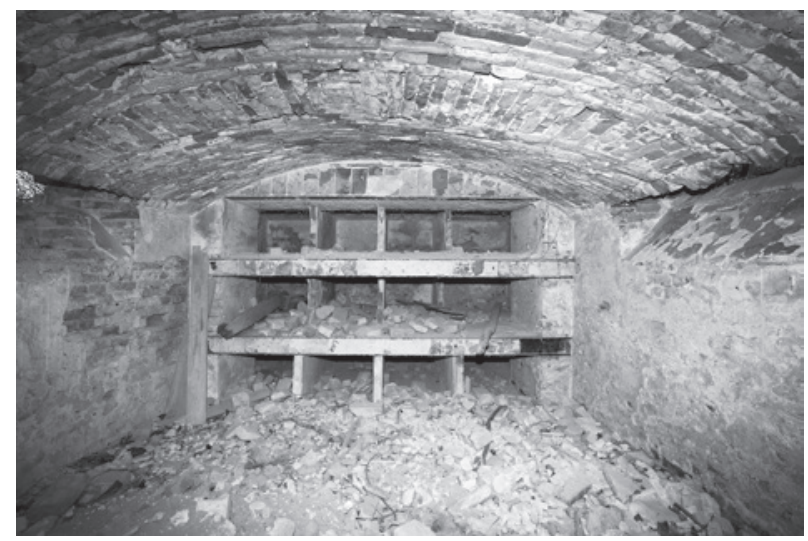

15. Az Ágoston-Kacskovics-sírkápolna kriptája. Szőlőskislak

Az 1838-ban alapított Miesbach-Drasche-féle téglagyár kezdetben igen kis mértékben, de gyártott "díszítési” téglát iszapolt agyagból, amik „színüket fémoxydok hozzákeverése által nyerték." A rákosi gyárban - 1868-tól Pesti Kőszén- és Téglagyár Társulat - 1873-ban az agyag iszapolását felváltotta a separator készülék használata, a márga- és mészkőrögök eltávolítására a nyersanyag minőségének 


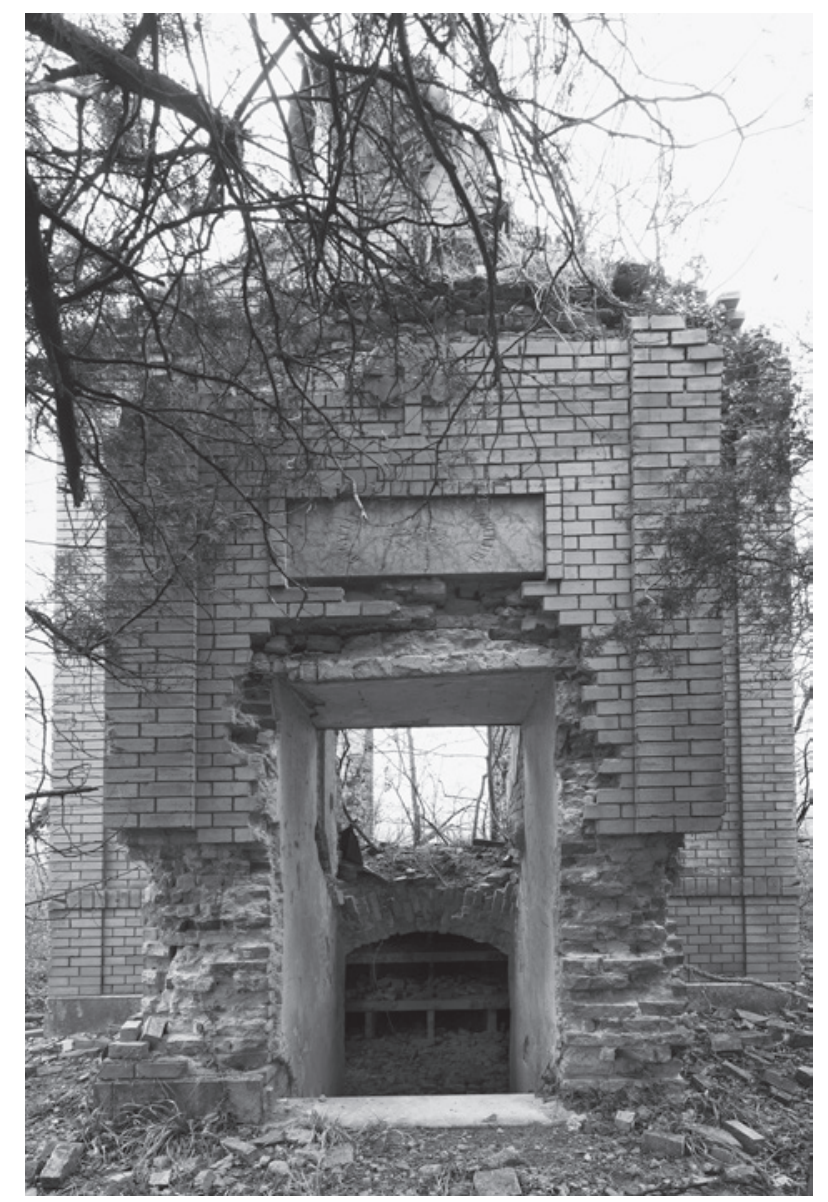

16. Az Ágoston-Kacskovics-sírkápolna kriptalejárata. Szőlooskislak

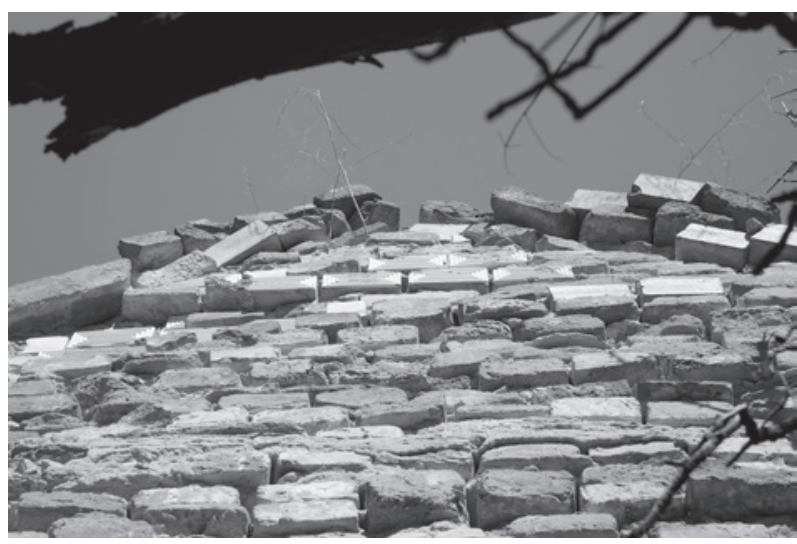

17. Mázas idomtéglák az Ágoston-Kacskovics-sírkápolna föhomlokzatának belső síkján. Szőlőskislak

javítása érdekében. A szárazon sajtolást a finomszerkezetü szelvényes, szintén sajtolt tégla gyártása váltotta fel a tisztított anyagból. Az építészek által megkívánt sárga és veres szín előállításához ekkor már fémoxidokat nem használtak. ${ }^{34}$

A Kacskovics-sírkápolna egy másik burkoló téglája, amely a timpanonból zuhant ki - az Isten sze- mét jelképező vörös mészkő háromszög köré volt rendezve -, még érdekesebbnek tünt; nemcsak az oromzatpár látszó oldalain, de a portikusz felettinek a tetőzetben lévő síkján is megtalálható. A mázas dísztégla porcelánfehér, bordázott felületét a bordák koncentrikusan, négy törtvonalú menetben keretezik; a középső, az ötödik csupán egy vízszintes elem. ${ }^{35}$ (17. kép) Csillogó, zománcos, lüszteres párja burkolja a kőbányai Szent László-templom homlokzatait, faltükreit. ${ }^{36}$ Az 1894 és 1899 között épült templomhoz Szabó Sándor építőmester csak „honi anyagot használt, mely kőből, téglából, s a terracottához hasonló pyrogranitból áll. Ezt az égetett agyagkeverékből álló anyagot Zsolnay honosította meg nálunk, ebből készültek Zsolnay kivitelében az összes ornamentikai és figurális díszítmények. Nagyon érdekesek a luxustéglák, melyeket a »Lechner rákosi téglagyár r.t.« szállított. E téglák hidraulikus nyomással készíttetnek, s elpusztíthatatlanok. A préselés által külső részük a la gréc (sic, kiemelés P. E.) van domborítva és az egyes mezőnyök ez által oly külsőt kapnak, mintha mozaikmezők volnának. Az első oldalon levő képen, [ti. a címlapon] mely fényképezés útján készült, láthatják olvasóink a mezőnyöket, melyek különösen napfényben vakítóan ragyognak. Ezek vörös téglák által környeztetnek. Ugyancsak a LechnerRákosi téglagyár r.t. különlegessége az úgynevezett disznóbőr tégla, melynek minden egyes darabja 5 forintba kerül. Ezek a téglák nagy ellenálló képességüknél fogva a betetôzéséhez [boltozáshoz?] használtatnak. Az építésnél használatban lévő mütéglák különféleségéről fogalmat alkothatunk magunknak, ha meggondoljuk, hogy nem kevesebb, mint 500 mintát készítettek külön e czélra, melyek mindannyian Lechner rajzai után mintáztattak" ${ }^{37}$ Szőlőskislakon a kripta járószintjét burkoló törmelékből mázas, rozettamotívummal díszített (sárga és barna színekben) járólap-töredék is előkerült: [Wiener]berger Wien gyártmány. ${ }^{38} \mathrm{~A}$ kápolnatér apszisa mellett a bal szögletben az omladék alatt feltártuk a meander szegélyezte rozettás padlózat részletét. (18 kép)

A tudós szőlősgyöröki plébános, Kozma László (tizedik a sorban) - Kislak a filiája volt - a Veszprémi Hírlap 1906-os évfolyamában a Csarnok rovatban cikksorozatban dolgozta fel plébániájának történetét, forrásokra támaszkodva. A „legújabb korban azonban a következő községekben épültek kisebbnagyobb kápolnák: Szöllős-Kislakon Kisjókai Ágoston József földbirtokos 1884-ben épített családi sírboltot, amelyben lehetőség szerint minden hónap 15-én Szent mise tartatik a sírboltban nyugvók lelki üdvéért."39 Szőllősy Lajos györöki plébános 1883. 


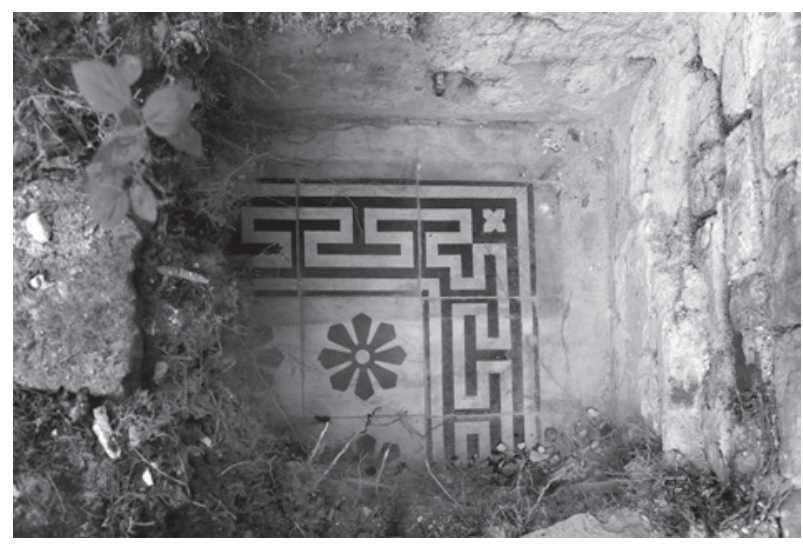

18. Padlórészlet meander-dísszel az Ágoston-Kacskovics-sírkápolnában. Szölöskislak

október 22-én levélben tájékoztatta püspökét, Kovács Zsigmondot arról, hogy „Szöllős-Kislak fiok helység temetője fölött bizonyos Kacskovits (sic) család egy kisded ugyan, de csinos kápolnát bejelentés mellett építtetni kezdett, amely alatt családi sírboltot is csináltatott. Én - mint Excellentiádnak is megmondám -, kinyilatkoztattam a megjegyzett családnak, hogy ezen épület csak azon esetre lehet a kívánt czélra fordítható, ha annak fenntartása és tatarozása tekintetében bizonyos s megfelelő összeg letéve nem lesz..." A beszámoló szerint a Kacskovics család 400 forintos alapítványt hozott létre az egyházi jóváhagyás végett. A levélben még olvasható, hogy a kápolna ugyan külsőleg készen állt már, de a "szükségesekkel felszerelve” még nem volt, ezért felszentelése csak a következő évben lehetséges. Ellenben azt kérte Szőllősy, hogy a sírboltot a folyó hó végével mégis felszentelhesse, mert a család „feje, boldogult Kacskovits Ignátz Tótgyugyról” áthelyezhető lenne, az „ő jó gyermekei által neki szánt költséges szép helyre áttéve". Egyben kérelmezte, hogy a szentelést maga végezhesse. ${ }^{40}$ A plébános 1884 . július 15-én kelt levelében megírta püspökének, hogy a feltételek teljesülése és az engedély birtokában előző évben felszentelte a sírboltot. Egyben jelentette, hogy a „csinos” kápolna elkészült, s az építtető ,,jó és buzgó család [azt] Loyola Szent Ignátz tiszteletére kívánja felavatni... innepnapján [VII. 31.] általam... ezen szent ténykedés igen nagy örömömre szolgálna". Folyó hó 18án még Veszprémbe is elutazik - jelezte -, hogy ott „egy Szent ereklyével ellátott oltárkövet a kápolna részére nyerhessek" ${ }^{41}$ A sírkápolna felszentelésének dátuma magával hozza a kislaki Kacskovicskúria, kiskastély építésének dátumát, bizonyosan 1883 elé. ${ }^{42}$ Ennek portikusza alól, a terület elvadultsága előtt rá lehetett látni a "végső" nyughelyre. ${ }^{43}$ A Lechner-design, bordázott dísztégla pedig egy

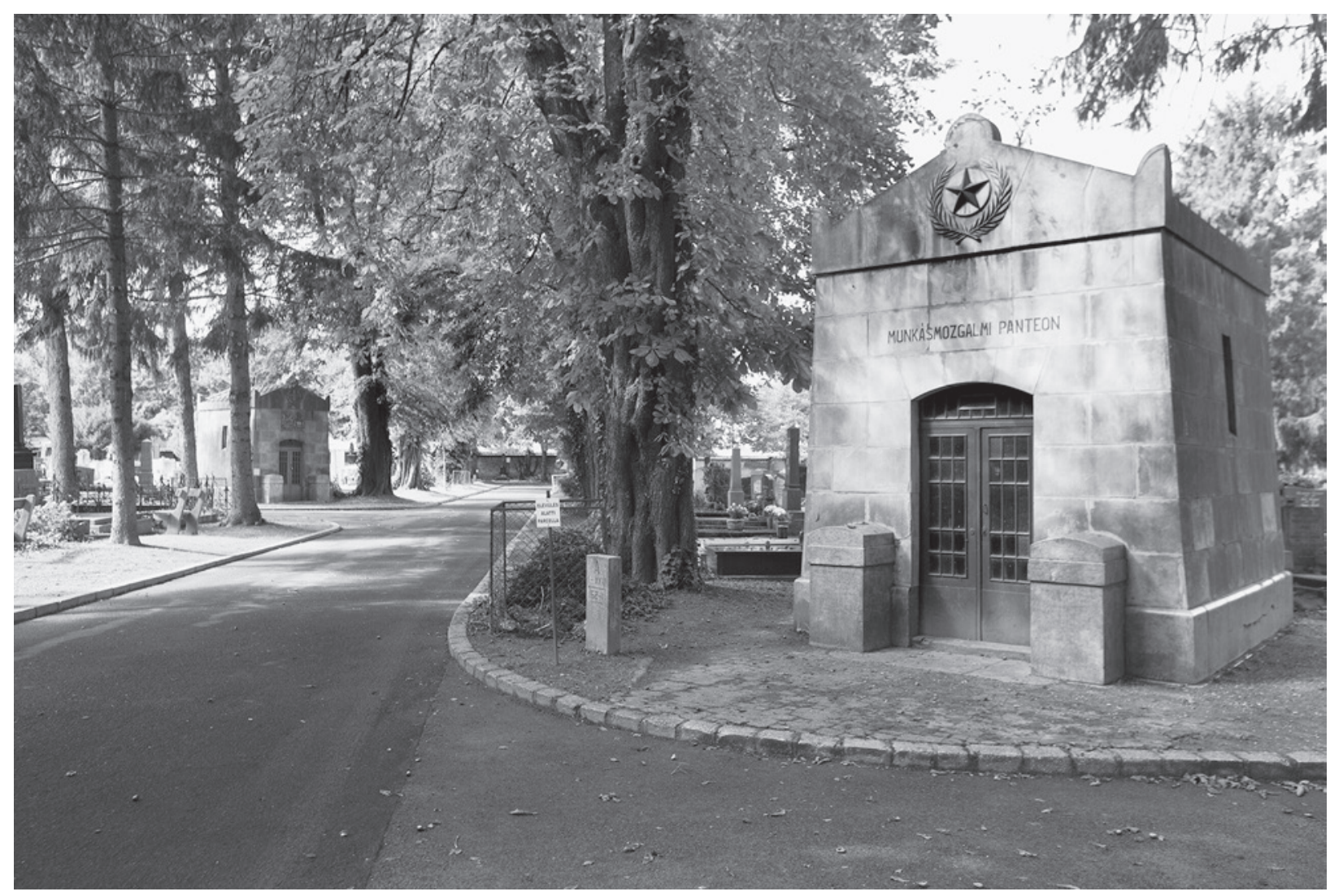

19. A Nagy-Gradvohl-és az egykori Littke-sírkápolna a pécsi temetőben 
évtizeddel korábbi fejlemény az említett alkalmazásokhoz képest.

Az illetékes egyházmegyék egyházkormányzati irataiban jó eséllyel kutathatók a bizonytalan datálású, de felszentelt építmények adatai. A tervezó építészek nacionáléja nem volt érdekes, ellenben a jó karbantartás biztosítéka annál inkább, s ezt dokumentálták. A szentelésról tudósított a Somogy címü hetilap: „Szőllős-Kislak községben augusztus elsején egy új katholikus templomot szenteltek föl, amelyet Ágoston József saját költségén s saját terve után renaissance-stílusban épített. Ágoston József mintegy 10 éve tért át a református vallásról a katolikusra s a templom építésére 10.000 frtot szentelt. A templomot Kacskovics Ignácz volt országgyülési képviselő hamvai fölé emelték $s$ felszentelésén az Ágoston és Kacskovics családokon kívül számosan jelen voltak a környék intelligentiájából. Az egyházi szertartást Szőllősy Lajos Szőllősgyörki plébános végezte." ${ }^{44}$

Kisjókai Ágoston József (Budapest 1844 - Szőlőskislak 1908) a m. kir. József Múegyetemen 1875ben a mérnökök között az oklevéllel egyenértékü absolutoriumot szerzett. ${ }^{45}$ Maga alkotta, színvonalas

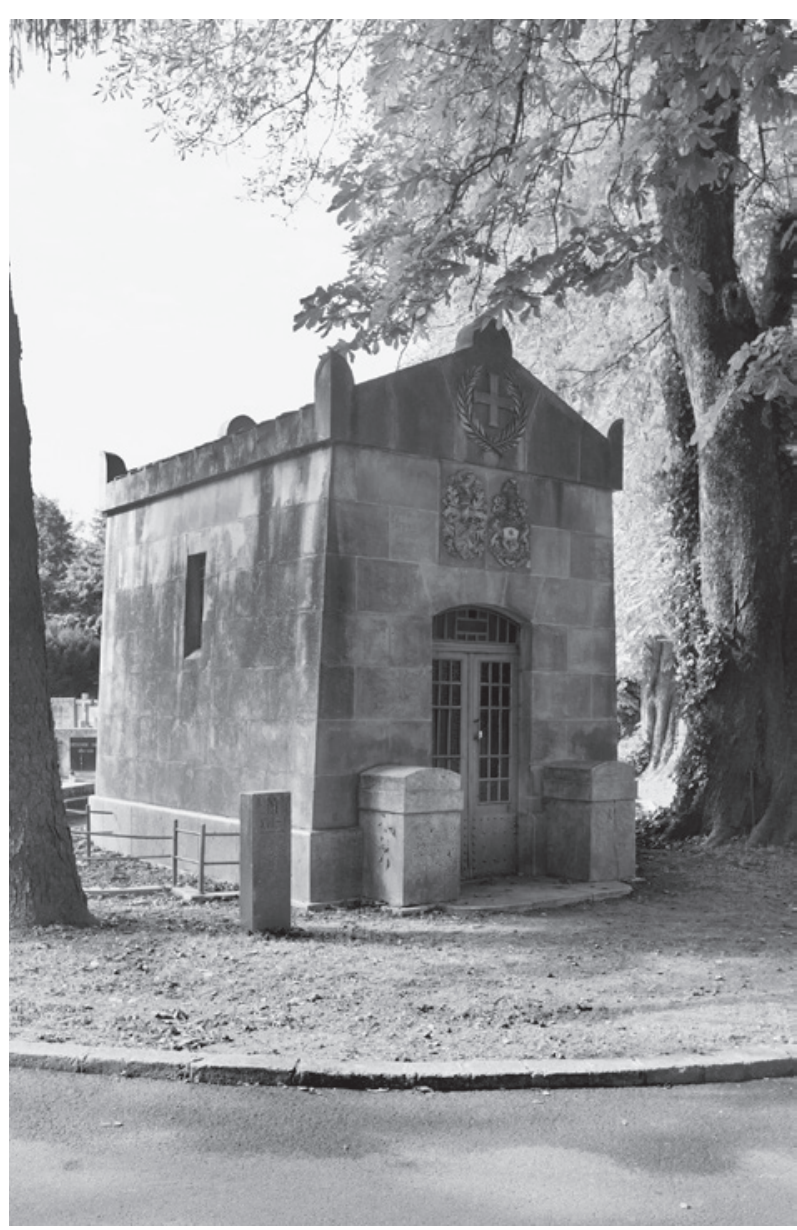

20. A Nagy-Gradvohl-sírkápolna a pécsi temetóben építészetet képviselő családi sírkápolnája, ami tulajdonképpen együttest képez a kastéllyal, még megmenthető és megmentendő a megye és a műemlékvédelem közös és gyors erőfeszítésében. A tervezett nemzeti mauzóleum-programban a talán kisebb jelentőségü emlékeket is illene számba venni. ${ }^{46}$

\section{Appendix}

Pécsett, a Központi Temetőben egymástól látótávolságra áll két historizáló, antik szarkofágot idéző kripta. (19. kép) Kékesszürke mázas lábazat felett emelkedik a kőszürke színü, trapéz keresztmetszetü tömeg, melyet a tetőgerinc végpontjain és a sarkokon akrotérionokkal hangsúlyozott, tegula jellegű héjazást mutató nyeregtető zár. Az M-parcella XVII. sorának 1-2. számú sírhelyén álló építmény szegmensíves bejárata felett kettős családi címer látható - a jobb oldali pajzs alatt PER ENSEM jelmondat olvasható -, az orommezőben pálmaág keretezte egyenlő szárú kereszt. (20. kép) Az A parcella XXVI. sorában a 60-61. számú helyen található párdarab sajátos metamorfózison esett át; a kereszt helyén ötágú vörös csillagot találunk, a bejárat felett pedig vörös színű festékkel kihúzott, vésett kapitális antikva betűs felirat: MUNKÁSMOZGALMI PANTEON. A temetőlátogató, amennyiben ez utóbbit pillantja meg először, az erőteljes klasszicizálás, a csillag és a megnevezés okán hajlamos lenne az ötvenes évek szocreál művészetének világába helyezni az építményt. (21. kép) A mázas lábazat és a kétszárnyú fémajtót szegélyező szalag-nyaktagos, domborodó felülettel záródó szecessziós törpepillér-pár azonban meggondolásra késztet. A családi mauzóleum falazatában a bal oldali mellett márkajelzést is találunk: a Pécs városára utaló öt torony bélyeget, alatta ZSOLNAY GYÁRAK / PÉCS / II. feliratot. Kertészeti elemmel is gazdagított ez a temetkezőhely, három oldalról félkörívvel bővített négyszögü virágágyással, amelynek a lábazati zónába bekötött fémpálca korlátja a már leírt mázas anyagú alapozásban áll. A „panteon” esetében eltávolították, mert az építmény megmozdult, s a szilárdan bekötött vasak az ívesen záródó és forduló lábazati elemeket végigrepesztették.

A Zsolnay Múzeumban is másolatban őrzött fazonkönyvek XII. kötetében a 3533-3542 tételek alatt megtalálható a "Nagy család mauzóleuma Pécs” méretezett rajzdokumentáció: lábazati és falazati elemek, a fedél az akrotérionokkal és a kereszttel, a kerítés lábazata, a (világos színű) belső burkolólap, a bordűr keresztmotívumai, a feliratos táblák kerete (ez utóbbi „pyrogránith” megjelöléssel) az 


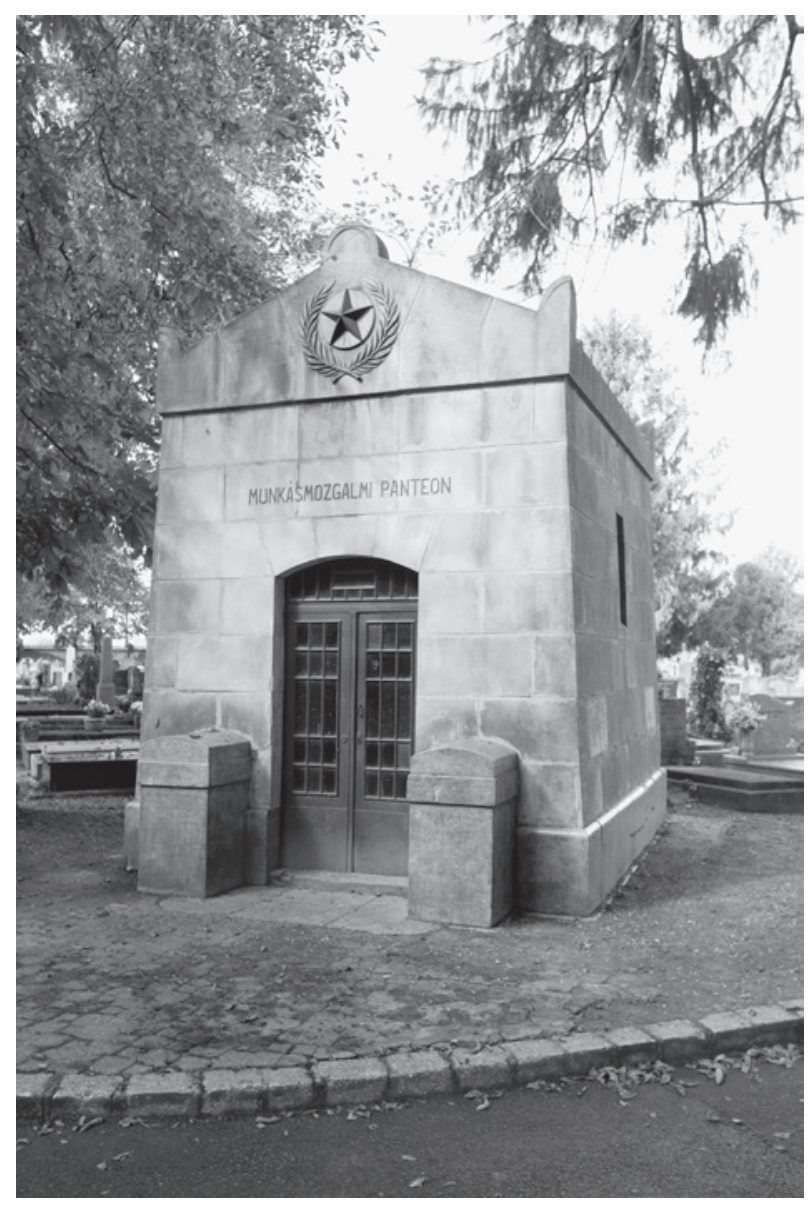

21. A munkásmozgalmi panteon (volt Littke-sírkápolna) a pécsi temetóben

apró fali oltármű részei a hozzá tartozó koszorú és kereszt. Úgy néz ki, hogy egy falazott téglamagot burkoltak kívülről a kőszerú terrakotta elemekkel. Egyes tervlapokon dátumok is szerepelnek, munkaforma megsemmisítve: 1909. X. ?, az oltármű 61 cm magas oszlopocskája: 1912. I. $12 .{ }^{47}$

Zsolnay Miklós 1909. március 12-én keltezett, Pécs város tekintetes Tanácsának címzett levelében Nagy Valér cs. és kir. altábornagy megbízottjaként kérte, hogy „a központi temetőben az M parcella II. számú sírbolt-helyre a mellékelt terv szerint Mausoleum építését"engedélyezzék. A mellékletben felsorolt $2 \mathrm{db}$ rajz nem lelhető fel, csupán egy költségvetés. ${ }^{48}$ Nagy Valér 1908-ban a K parcellában egy különleges s ezért újraértékesíthetố síremléket készíttetett leánya számára és a különbözetet beleszámították az építendő költségeibe. Szentkirályi Nagy Valér apja a szabad királyi város polgármestere, anyja Gradvohl Borbála, felesége pedig a neves pécsi orvos, $\mathrm{Pa}(\mathrm{z})$ sitzky Ede lánya, Angéla volt. A címerek közül a „kard által” iratszalagos, azaz a fegyverrel szerzett nemesség a Gradwohl családot - kardot tartó kar, felette hatágú csillag -, a másik

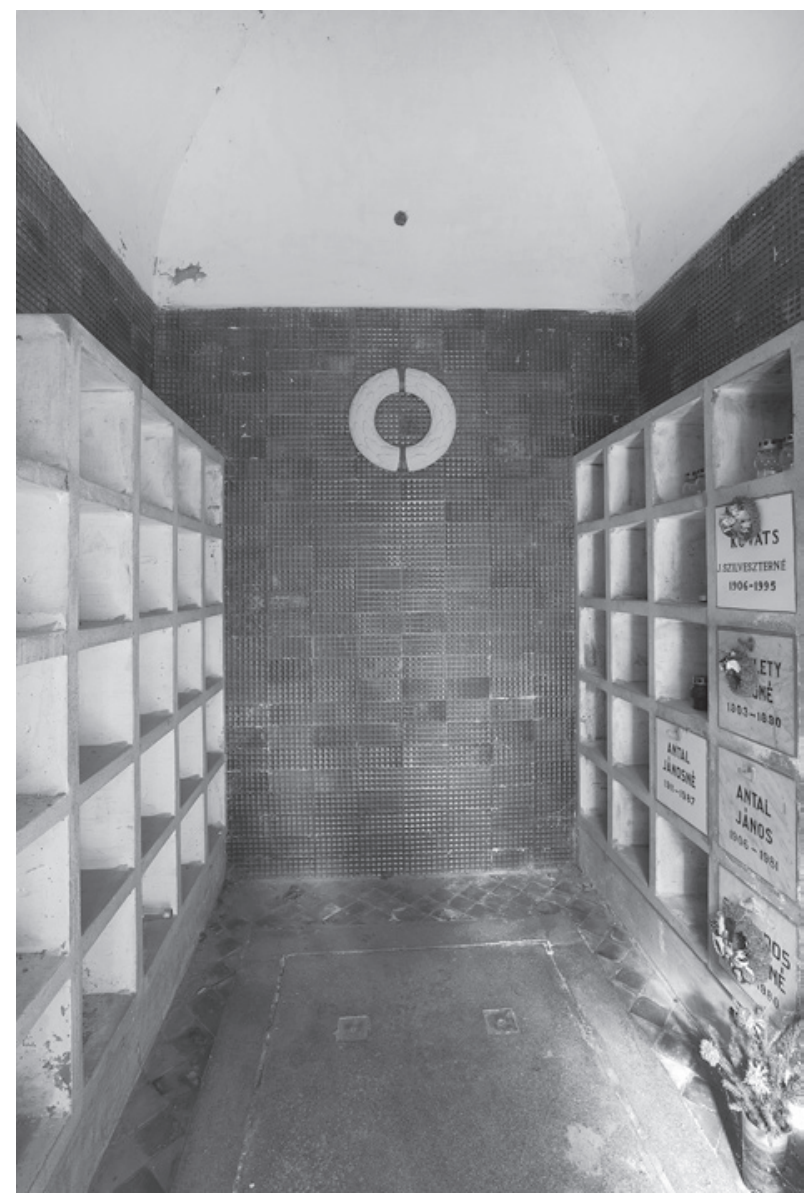

22. A munkásmozgalmi panteon belseje. Pécs, temető

- jobbra lépő, kettős farkú oroszlán - a Nagy családot jeleníti meg. ${ }^{49}$

A mostani Munkásmozgalmi Panteon eredetéről az elért levéltári források hallgatnak. ${ }^{50}$ Ellenben a városi pártbizottság 1963. augusztus 2-i ülésén tárgyalt és döntött a panteon sorsáról napirendjének 4. pontjában, az „Egyebek” alatt. „Az öreg párttagok Pártbizottsága a temetőben egy mauzóleumot akar kialakítani, melyben a munkásmozgalomban részt vett elvtársakat helyeznék hamvasztás után egy urnába. 64 urna lesz. Dicsérendő, hogy a városi KISZ Bizottság patronálást vállalt. A temetkezési Vállalat biztosította a mauzóleumot, csupán felújítani kell ezt a helyiséget. Elkészítették a tervet is. A KISZ B. vállalja a munka elvégzését is, csupán a Városi Tanácsot kérjük az [építő]anyag biztosítására. Az anyag egész minimálisköltségbe kerül, és 1-2 évig elegendő lesz a hely a veterán elvtársak részére." ${ }^{\prime 1}$ (22. kép)

A panteon létrehozásának mozgatói között ott szerepelhetett az 1958-ban a fővárosban a Kerepesi úti temetőben átadott „nagyszabású, a munkásmozgalom nagy halottainak" állított monumentum, mely alkotásért 1959-ben Olcsai Kiss Zoltán és 


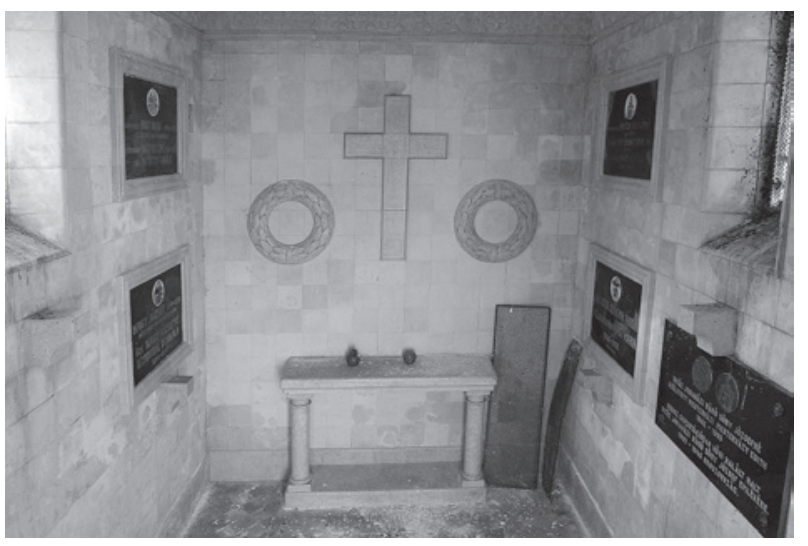

23. A Nagy-Gradvohl-sírkápolna belseje az oltárral. Pécs, temetó

Körner József szobrász-építész páros az irodalom és a művészet kategóriában Kossuth-díjat kapott. ${ }^{52}$

A panteonban a fentebb leírt külsőt érintő beavatkozások mellett a belsőt gyökeresen átalakították. A teknőboltozatos térben a hosszoldalak mentén kolumbárium-falat húztak fel, ami azt eredményezte, hogy csupán egyetlen pyrogránit koszorút hagytak meg (szalagját pirosra kenték) a bejárattal szemközti - fekete, apró négyzetekkel mélyített mezős (helyi gyártású?) csempékkel burkolt - falazaton, valamint az eredeti járólapok keretezte kriptafödél bronz emelőkarikái nélkül.

Egy hajdani újsághirdetés megvilágítja a hétköznapian prózai valóságot, miért is erre a sírboltra esett a választás. A Baranya Megyei Temetkezési Vállalat igazgatója tette közzé az alábbi felhívást: „A temető Szabályrendelet 15. paragrafusának 5. pontja szerint a nem gondozott és omladozó állapotban lévő sírboltok, mauzóleumok 30 év elévülési idő után a temető fenntartójának tulajdonába mennek át. Felhívom ismételten Szentkirályi Nagy Valér családi sírbolt (M tábla) és Littke Ágoston [a pezsgőgyáros família] családi sírbolt (A tábla) tulajdonosait, illetve hozzátartozóikat, hogy a köztemető irodájában nyolc napon belül jelentkezzenek a sírboltok helyreállítása végett. A jelentkezési határidő lejárta után a vállalat a sírboltokat igénybe veszi és a benne lévő térben lévő tetemmaradványokat eltávolítja." ${ }^{53}$ (23. kép)

A történeti hűségnek tartoznánk azzal, hogy jelen státusukban őriznénk meg a romló állaguk ellenére is a különös minőségü és történeti érdekességű mauzóleumpárt, úgy is mint védett műemléket.

\section{JEGYZETEK}

1 Az Ovidius-hely Devecseri Gábor fordításában: „s mit hullat Jupiter terebélyes tölgye, a makkot." Publius Ovidius Naso: Átváltozások. Ford. Devecseri Gábor. Budapest 1975, 10. (Metamorphoses I., 105.) Az Ószövetség használja az emlékkő terebintfája és a gyásztölgy kifejezéseket, képeket. Herbert Haag: Bibliai lexikon. Ford. Ruzsiczky Éva. Budapest 1989, 1843: Tölgy. L. még: Bír 9,6; Ter 35,8.

2 „Tervezte / Gerster Kálmán és Strobl Alajos”.

3 Budapest, Magyar Nemzeti Levéltár, Országos Levéltár (a továbbiakban MNL OL): T-8. Gerster Kálmán - h. Nr.18:144; mécsestartó terve, 142; oromzatterve, 143; Brüll család sírboltja; oldalhomlokzat, főhomlokzat, metszet a kriptával, keresztmetszet, kripta alaprajz és alaprajz (M=1:20, 74,5×115 cm). Vö. Papp Gábor György: Gerster Kálmán síremléképítészeti munkássága. Ars Hungarica XXX. 2002/1, 49-122; Brüll-síremlék: 101-104. Uő: Mauzóleumok. In: A magyar múvészet a 19. században. Szerk.: Sisa József. Budapest 2013, 415-424.

4 A hagyományok szerint sírkő felállítására az elhalálozás első évfordulója alkalmából került sor. L. Komoróczy Géza szerk.: A zsidó Budapest. Emlékek, szertartások, történelem. Budapest 1995, 582-610. (XIII. Zsidó temetők)

5 Budapest Főváros Levéltára (a továbbiakban BFL) XV. 17.d. 328. Brüll Te-171.d. M=1:20. J. j. 1.: Gerster Kálmán és Stobbe (és Blachó) felelős építőmester. Papp Gábor György Gerster Kálmán munkásságát feldolgozó doktori disszertációjában $(2007,112$.) megismétli a 2002-es publikációjában leírtakat: a Brüll család síremlékének timpanonjában „arany mozaik háttér előtt kiterjesztett szárnyú griff domborműves alakja látható." Gömöry Judit és
Csomortány Levente 2016-ban írt építéstörténeti tudományos dokumentációjukban - Bp. X. Kozma u. 6. (42533. hrsz.) Brüll-síremlék - írják: a "timpanon arany mozaik hátterü mezeje előtt kiterjesztett szárnyú, az ikonográfiai jobb oldalra fordított fejü, szalagokkal átfogott rőzsekötegen ülő sas háromnegyed domborműve látható." (4.) Az emléket 2016-ban restaurálták: Molnár Gabriella és Rácz Krisztina (mozaik); Csányi Szabolcs és Szomolányi Péter (kőszobrok); Páhi Attila (fém). (Az áttört mustradíszes bronzajtó rekonstrukciója nem hiteles - Csáki Tamás tájékoztatása. Vö. Vizler Imre fényképfelvételei 2005, 2009. Kozma u. - Neológ Zsidó Temető. Jobb oldali mauzóleumok: 03 - Brüll; 14., 18., 47. képek. Fővárosi Szabó Ervin Könyvtár, Budapest Gyűjtemény.) Építész: dr. Mezős Tamás.

6 A budai várban, a Szentháromság téren a Pénzügyminisztérium palotatömbje (1901-1904) teljes tetőzetének ácsmunkája ugyanennyibe került. Fellner Sándor: A Magyar Királyi Pénzügyminisztérium Palotája. Budapest 1908,8 .

7 Építő Ipar XXVII. 1903, 39-42. Egy korabeli beszámoló szerint: „Ki hinné, hogy elrejtve a világtól... múvészi körökből is alig ismerve milliókat érő kincsei tárulnak itt elénk [ti. zsidó temetőben] a müvészi architekturának! Káprázatos fényű családi kripták... bizánczi, ó-perzsa, egyiptomi stílben... szecessziós ízlés[ben]... pompájával válik ki a Brüll-család mauzoleuma, színes festett fölsejével [?] és mozaik díszével." V. S.: A Kőbányai új temetőben. Vasárnapi Ujság LIII. 1906/45, 736-737. A Hatsek család mauzóleumát ábrázoló fényképen látszik a Brüll-emlék jobb oldali részlete az „új izr. teme- 
tőben". Schmidt Gyula (műépítész és kőfaragó mester, Budaörsi út 17-19.): Individuális síremlékek és szobrok. H. n. é. n., 69. Fővárosi Szabó Ervin Könyvtár, Budapest Gyüjtemény, B726/9.

8 Vanyó László: Az ókeresztény müvészet szimbólumai. Budapest 1988, 192-201.

9 Erwin R. Goodenough: Jewish Symbols in the Greco-Roman period. New Jersey (1953) 1988, 49, 56, 60. A szerző a szimbólumok természetének megvilágítására (i. m. 40.) Ovidius müvéből, a Hősnók leveleiből idézett (Heroides XIII., 155): „Crede mihi, plus est, quam quod videatur, imago" - „Lásd, e szobor nékem sokkal több puszta alaknál, higgyem..." (Publius Ovidius Naso: Hősnők levelei. Ford. Muraközy Gyula. Budapest 1985, 77.) Ismerünk olyan ábrázolást, amelyiken a kiterjesztett szárnyú sas karmai között villámcsóvát, csőrében pedig makkot tart. Pecz Vilmos szerk.: Ókori Lexikon. Budapest (1902) 1984, 186: Aquila, 91. ábra. L. további példákra: The Warburg Institute Iconographic Database (Jupiter) ismeretét Ágoston Juliannának köszönöm.

10 Erdélyi Lajos: Régi zsidó temetők müvészete. Bukarest 1980, 23-25: a sztélé típusú sírkövek sas ábrázolásairól. A Physiologus a sasról: „Dávid mondja: Megújul a te ifjúságod, mint a sasé." In: Physiologus. A Zsámbokikódex állatábrázolásaival. Ford. Mohay András. Szerk.: Márton András. Budapest 1986, 16-17. A klasszicista bajai zsinagóga (Frey Lajos, 1842-1845) frigyszekrénye mögött a baldachinos drapériát sasok emelik. (A díszítőelemek között feltünik a Szent Korona kereszt nélkül.) Klein Rudolf: Zsinagógák Magyarországon, 1782-1918. Budapest 2011, 192-193.

11 Horler Miklós et al.: Budapest múemlékei, II. (Magyarország müemléki topográfiája, VI.) Budapest 1962, 425-429, különösen 393. kép. Ez a „négyoszlopos” bima térszerkezetei váltás eredménye - a csehboltozatot megelőző kilencosztatú tér maradéka - lenne. És a sasok „,központi helyen történő megjelenítése rokonságot mutat a nem-zsidók hatalmi jelképeivel". Klein Rudolf-Nagy Gergény Domonkos: A zsidó vallási reform építészeti tanúja az óbudai zsinagóga. Magyar Építőművészet 2017/1., 57-63.

12 Az emlék 2017 tavaszára a Nemzeti Örökség Intézet égisze alatt újult meg, generálkivitelező a BTI Nemeskő és Építőipari Kft. volt.

13 Művészet II. 1903, 426. Békás-Timapusztára az a téves feltételezés vezetett el, hogy a Brüll-síremlék mozaik-kompozíciója Kölber Dezső (1874-1945) munkája is lehet. Ugyanis a díszítőfestészet tanára közreműködött a Gerster-Stróbl páros tervezte Kossuth-mauzóleum munkáiban. Építő Ipar XXXII. 1907. XI. 7., 411-413; valamint Gerster építette Kölber mütermes lakóházát a XI. kerületben, a mai Ábel Jenő utca 29. sz. alatt. I. h. IV. 13., 217.

14 Magyar Mérnök és Építész Egylet (MMÉE) Heti Értesítője XXII. 1903. november 8., 231-233, 236.

15 Heti Értesítő XIX. 1900. május 30. Életére 1. Lipthay Sándor: Hollán Ernő emlékezete. Építő Ipar XXVI. 1902, 124-125, 127-130, 139-141, 147-148.

16 Jelezve j. 1.: Závory Z[oltán]. 71. A művész (19062000) Dudits Andortól tanulta a falképfestést. F. Almási Éva szerk.: Kortárs magyar müvészeti lexikon III. Budapest 2001, 951.

17 Kostyál László: Kisfaludi Strobl Zsigmond élete és müvészete. Zalaegerszeg 2014, 141, 220. (361. sz.) -
Kostyál László monográfiájában Békássy Ernő epitáfiuma nem szerepel.

18 Ybl Ervin: Ybl Miklós. Budapest 1956, 28-29, 120, 127.

19 Uo. 198, 200. Gerle János és Marótzy Kata szerk.: Ybl Miklós. Budapest 2011, 20-23, 64-65 (Nagycenk).

20 Veszprém Érseki és Főkáptalani Levéltár (a továbbiakban: VÉL), Egyházkormányzati iratok. 202/1871.

21 VÉL 581/1869.

22 VÉL 930/1869. A nyilatkozatot október 13-án küldte meg Veszprémbe. 1235/1869. október 19. 1300/1869 (a család iskolát is szándékozott emelni Békáson).

23 Vö.: Halász Csilla szerk.: Ybl összes. 52 település 113 épület. Budapest 2015, különösen 242-253 (Az emlékezet építményei). A Budapest Főváros Levéltárában lévő Yblhagyatékban több azonosítatlan funerális emlék terve található. Farbaky Péter - Kemény Mária szerk.: Ybl Miklós építész 1814-1891. Kiállítási katalógus. Budapest 1991, 170-173.

24 A hetvenes évek közepéről a kajdacsi emlékkápolna - „stylje... a dél-franciaországi román, hanem kissé modernizált idomokkal" - Yblnek Ney Bélával bizonyosan közös műve. A Magyar Mérnök és Építész Egylet Közlönye X. 1876, 526. és XXIV. tábla, ez újraközölve: Melléklet az Építési Ipar 1877. II. számához. Az ismertető szerint sírkápolnának nem mondható a Tolna megyei Kajdacson álló Sztankovánszky-kápolna, mert a koporsófülkék a kápolnán kívül sugárirányban a földben helyezkednek el. Az építmény, melyben mise évente kétszer szokott mondatni, 20 ezer forintba került. Ybl nagy változatosságban oldotta meg a szakrális és funkcionális feladat-együttest a típusban. Az attribúció kérdésköréhez 1. Vadas Ferenc: Egy Ybl-terv szerzőségéről. In: Uő szerk.: Romantikus kastély. Tanulmányok Komárik Dénes tiszteletére. Budapest 2004, 314-331. L. még: Magyarország müemlékjegyzéke. Tolna megye. Összeállította Csejdy Júlia, szerk. Lővei Pál. Budapest 2006, 51. (Cser István)

25 Hrsz.: 0147/9. Vö. Deák Varga Dénes: Somogy megye kápolnái. Kaposvár 2002, 18. Fotó. A bozótosban „a kastélypark szélén a temető fölött magasodó domb ormán magasodik” a feldúlt, beszakadt tetőzetü „,antik görög templomot idézö" Kacskovics-mauzóleum; formájáról ítélve a „XIX. sz. végén készülhetett” (uo.). Kislakon Velladics Mártával a Jánossy György típusterve alapján 1951 körül épült múvelődési házat helyszíneltük, a kápolnára Csere Andrea könyvtárvezető hívta fel a figyelmünket.

26 Csánki Dezsó szerk.: Somogy Vármegye. Budapest é. n. [1914,] 73. A Kacskovics-bélyeges téglákra 1. Dibusz Ferenc: Gyugy községi kirándulás. Jeles téglák, jeles emlékeink, 6. H. n. 2012, 94-95.

27 Vö. Nagy Iván: Magyarország családai czímerekkel és nemzedékrendi táblákkal. I. Pest 1860,10; VI. Pest 1875, 12-13; Kempelen Béla: Magyar nemes családok I. Budapest 1911, 48-49; Csánki i. m. (26. j.) 82, 614 és passim; Vasdényey Imre: Ósi birtokok és birtokosok Somogy Vármegyében. Kaposvár 1922, 17-18, 36.

28 Brózik Zsófia - Pálinkás Eszter - Vincze Attila: Szőlősgyörök, Jankovich-kastély parkja. Kerttörténeti tudományos dokumentáció. Budapest 2014, 18. Fülöp Andrásnak ezúton is köszönöm, hogy felhívta figyelmemet a munkára.

29 Méretei: $14,5 \times 6,5 \times 6,5 \mathrm{~cm}$. Nagyméretü, szintén jelzett, $7 \times 7 \times 30 \mathrm{~cm}$-es változata is található a törmelék- 
ben, valamint K[acskovics] I[gnác] monogramos építőtéglák.

30 Kádár József: Kőbányai téglagyárak. Magyar Műemlékvédelem XIII. Szerk.: Bardoly István. Budapest 2006, 307-372.

31 Lechner Ödön: Önéletrajzi vázlat. A Ház IV. 1911, 343. A Cégbíróság anyagában megőrződött cégaláírási címpéldány szerint: „Néhai »Lechner Nepomuk János [†1884. IV. 22.] hat nagykorú gyermeke [köztük Lechner Ödön] « czég alatt közkereseti társasággá" alakult, 1885. V. 8-án. BFL VII.2.e.Cg.129/1885. A „Lechner Nepomuk János utódai" téglagyár 1895 és 1917 között Lechner Rákosi Téglagyár Rt. formában működött. A tégláin az LRT betücsoport bélyeget használó gyártóra lásd Kádár i. m. (30. j.) 331-332.

32 BFL XV. 17.e. 306.1131.d.2417. Vö. Komárik Dénes: Budapest VII. Dohány utca 2-8. Tudományos dokumentáció I. (Zsinagóga) FIMÜV, Budapest 1989. IV. 20., 93. A terrakotta díszítményeket a „Fabrik von Heinrich Drasche (Alois Mieschbachs Erbe) aus Inzersdorf am Wienerberg" szállította. Az építőmester, Hild József csődjét követően kivált az építkezésből, ami eredményezhetett beszállítói váltást. Komárik Dénes: A pesti Dohány utcai zsinagóga építése. Mưvészettörténeti Értesítő XL. 1991, 1-16.

33 Magyar Zsidó Levéltár II-C-I-I B9/4 d.79.243 ltsz. Thonwaren Fabrik zu Wagram bei Loebersdorf, Victor Braussenwetter.

34 Zsigmondy Vilmos: A rákosi Drasche-féle téglagyár. A Magyar Mérnök és Építész Egylet Közlönye XV. 1881. VI. füzet, 493-501. Az új módszer szerint sajtolt díszítési téglát nagyobb mértékben először az osztrák államvasúti indóháznál (pl. Budapest, Nyugati pu. 1872, 1. uo. 74-77.) használták, ,jelenleg” pedig az épülő Polytechnikumnál. Vö.: A Pesti Kőszén- és Téglagyár-Társulat (MiesbachDrasche 1838-1868, utóda) gyártmányai: „Homlokzatdíszítmény-kövek nyersépítményekhez" sárga, szürke és vörös színben „részint szárazon sajtolva, részint vágva”. Az Építési Ipar I. 1877, mümelléklet, 2. tábla. Az Építési Ipar büszkén számolt be arról, hogy Bécsben a Schmidt Frigyes tervezte Stiftungshaus (a Ringstrassén), oldalhomlokzati téglaburkolatai Wienerberger "terményei" helyett „rákosi műtéglából állítattnak elö” Uo. VII. 1883. XII.16., 466. L. még: Mendöl Zsuzsa: A Zsolnay épületkerámia egy évtizedes bécsi sikertörténete. Magyar Müemlékvédelem XIII. Szerk.: Bardoly István. Budapest 2006, 295-306.

35 Méretei: 7,3×15×15 cm, jelzés nélkül.

36 Méretei: $7 \times 15,5 \times[$ ?] cm; mélysége kérdéses. Az Iparmüvészeti Múzeum homlokzatát (átadva 1896) $4+1$ és $5+1$ bordás, fehér és sárga mázas változatai burkolják nagy felületen. Kornélia Hajtó: Zsolnay Pyrogranite: Tradition and Fact. Separatum. Ars Decorativa 30. Budapest 2016, 125.

37 Magyar Géniusz VIII. 1899. IV. 16. 242. A szövegből úgy túnik, hogy a "disznóbőr" tégla nem azonos a „luxustégla” betéteket keretező sávok piros téglájával. A mütéglák 500 mintája és az épületen alkalmazásra kerültek száma között jelentősnek tünik a kontraszt.

38 Méretei: $17 \times 17 \times 1,8 \mathrm{~cm}$. Fóton, a templom hosszháza mellett futó árkádpár burkolata ugyanez a lap.

39 A Szöllősgyörki Plébánia története. Összeállította Kozma László. Veszprémi Hírlap XIV. 1906. III. 11., 25; IV. 1., 15, 22; V. 6., 27; V. 13., 5. A györöki plébánia Historia
Domusa (és Protocollumok?) az ezredforduló tájékán még megvoltak, jelenleg mind lappang.

40 VEL 1588/1883.

$41 \mathrm{Az}$ engedélyt a szentelésre Zsigmond püspöktől megkapta. VÉL 1140/1884. Július 18-án Devics József kezelő kanonoknál Szőllősy a kápolna részére kiszolgáltatott oltárkőért az egyházmegye pénztárába 3 forintot be is fizetett. Uo. 1156/1884.

42 Kacskovics Ignácz 1873. január 30-án kelt végrendelete szerint a „Kis-Laki határban” lévő birtokait (férjezett) Hermina lánya örökli, akit a vagyonba 1879-ben iktattak be. MNL Somogy Megyei Levéltára; XIII.16.1. doboz (végrendelet), XIII.16.3. doboz (beiktatás).

43 Daruvári Kacskovics Hermin Madách Emmanuel feleségeként hunyt el 1922-ben. Kiskastélyuk ezt követően került Gaál Franciska színésznő tulajdonába. A „Gaálkúria... a szép parkban álló eklektikus épület... 1902-ben Ágoston József tervei alapján épült. (Műemlékileg védett)"- írta Koppány Tibor A Balaton környékének müemlékei c. kötetében. Budapest 1993, 205-206. Az ÁgostonKacskovics-sírkápolnáról nem emlékezett meg, miként a györöki Jankovich-kastély parkjában állóról sem, melyet Jankovich Tivadar építtetett 1891-ben, és oltárát „,nevezett év szeptember havának 4-én br. Hornig Károly megyés püspökünk consecrálta". Megjegyzendő, hogy a kripta lejárója felett itt is egy zárt, üres (?) térrész található. Az épületet burkoló dísztégla KT bélyeges, a Kerámia Téglagyár terméke. (A kripta padozatának szegélysora egyezik a kislakival.) Bogláron, a Körmendy-család temetőkápolnáját Koppány 1856-ra datálja (uo. 208.). A Veszprémi Hírlap idézett helye szerint 1894-ben építtette Körmendy Lajos.

44 Somogy. Politikai és vegyestartalmú hetilap a szépirodalom, művészet, nevelés, ipar, kereskedelem, gazdászat köréből XX. 1884. augusztus 2. (2.). A lapban számos, Kaposvár és környéke építkezéseire vonatkozó adat található.

45 Névjegyzéke mindazoknak akik a m. kir. József Műegyetemen 1928. évi június hó végéig oklevelet, absolutoriumot vagy oklevélhonosítást nyertek. Budapest 1929, 221. (A mérnöki szakosztály megreformált tanrendjére 1. A m. k. József Müegyetem. Magyar Mérnök és Építész Egylet Közlönye 1882, V. füzet, 346-347.)

46 A kézirat lezárása után jutott tudomásunkra, hogy Deák Varga Dénes városi fóépítész (Nagyatád) kezdeményezte a Balatonboglár-Szőlőskislaki Kacskovicssírkápolna védetté nyilvánítását. Herczeg Renáta a Kulturális Örökségvédelmi Hivatalban 2004-ben el is készítette a "Javaslat műemléki értékek védetté nyilvánítására" c. dokumentációt. Ebben a kápolna megáldásának, megszentelésének dátumainak meghatározása a Veszprémi Érseki Levéltárban őrzött és fentebb bemutatott dokumentumok alapján történt. A tulajdonos, ill. a leszármazottak elmondása alapján rögzítette, hogy a kápolna boltozata kékre lett festve arany csillagokkal, színes üvegablakait az 1940-es években cserélték, és a kripta ajtaja az apszis mellett még fellelhető volt. Attribúciós kérdésekkel nem foglalkozott. A kezdeményezés eredménytelen volt, az emlék állaga pedig tovább romlott.

47 Pécs, Zsolnay Múzeum, Adattár.

48 MNL Baranya Megyei Levéltára (a továbbiakban BML), Pécs város tanácsának iratai, gazdasági ü. o. IV.1406.e. C-6412/1909. (Valamint évrendes tanácsi mutatókönyvek.) 
49 A családtörténetekre 1. MNL BML Kézirattár. Síkabonyi Angyal Pál helytörténeti anyaggyüjtése, VIII. k. - Pécsi Napló 1908. VIII. 8. Dőry Lajos: A Szentkirályi Nagy Valér család története (ltsz. 1956); Mészáros Balázs: Egy pécsi orvoscsalád életkörülményei a századfordulón (ltsz. 1958). A mauzóleumban nyugvók (Zsolnay-keretbe foglalt) emléktábláit ismertette Sey Gábor: A pécsi köztemető címer érdekességei. In: Mecsek Egyesület Évkönyve, 2007. Szerk. Baronek Jenő. Pécs 2008, 263-272.
50 A köztemető ún. Fókönyve szerint 1911-ben temették ide Lőrinczbányai Littke Ágostont. A temetőre ld. Petrich Csaba: Gesztenyefák árnyékában. 100 éves a Pécsi köztemető. Pécs 2004.

51 MNL BML XXXV. 9. MSzMP Pécs Városi Bizottsága iratai. VB ülési jkv. 1963. VIII. 2. (Ti/V/42/1963).

52 Népszabadság, 1959. III. 15. Prakfalvi Endre - Szücs György: A szocreál Magyarországon. Budapest 2010, 133.

53 Dunántúli Napló XX. 1963, III. 8., 4.

* A tanulmányban szereplő fényképeket Bélavári Krisztina készítette.

\section{TWO SEPULCHRAL CHAPELS IN THE HISTORICAL VESZPRÉM DIOCESE: BÉKÁS AND SZŐLŐSKISLAK - WORKS BY MIKLÓS YBL AND JÓZSEF ÁGOSTON}

The research was triggered off by the documentation of the building history of the mausoleum of the Brüll family in the neolog Jewish cemetery in Kozma street, Budapest. The revived antique, in ante temple style mausoleum erected over a crypt was completed in 1902 as the joint work of architect Kálmán Gerster and sculptor Alajos Stróbl. The interior of the cell is adorned with a fine floral mosaic composition (cartoon by Ferenc Lohr).

At Békás in Veszprém county the sepulchral monument of the founder of the Society of Hungarian Engineers and Architects was unveiled in the Békássy-Hollán mausoleum in 1903. The periodical Müvészet reported that the frescoes were painted by Dezső Kölber after cartoons by Károly Lotz. Documents in the Archives of the Veszprém Archiepiscopacy and Collegiate Chapter reveal that the chapel built in revival gothic style was consecrated on the day of the Sacred Name of the Virgin, on 12 September 1869, so that masses could be celebrated for the salvation of the departed souls. The church demanded that the builders provide guarantees for the survival of the chapel "until the end of time". The architect's name is not put down, but the article of 1903 expressly names $\mathrm{Ybl}$ as the planner of the funerary chapel, which has not been listed in his oeuvre so far.

During an assessment of art historical values we came across the ruins of the Ágoston-Kacskovics family's mausoleum on the edge of Balatonboglár, in Szőlőskislak. Until 1993 the diocese of Veszprém also included Somogy County. The remains of the archaizing building displays several remarkable elements. One is the set of wall-lining bricks stamped with the initials LNJ, which are undoubtedly from the brick-yard of the architect Ödön Lechner's family in Kőbánya. The other is a glazed, ribbed-surface ornamental brick type arranged around the red triangular limestone symbolizing the eye of God in the pediment. Earlier, this brick type was known on the St. Ladislaus church in Köbánya and the façades of the Museum of Applied Arts (1896) both planned by Lechner. The floor pavers - produced by Wienerberger - were acquired in Vienna. It is again the obligation for maintenance in good condition that accounts for ample documents kept in the Archiepiscopal Library, which re- veal that the crypt was consecrated in 1883, the chapel in 1884, on the feast day of Saint Ignatius Loyola. The erection of the chapel might have been related in connection with the re-burial here of landowner Ignácz Kacskovics, lord lieutenant of the county (and maybe with the change of the manorial centre). The use of the Lechner "design" bricks here precedes the well-known examples by a decade. The building was designed by József Áoston of Kisjóka, who qualified as an engineer from the Technical University of Budapest in 1875.

In the central cemetery of Pécs there are two similar historicizing family mausoleums close to each other. The classicizing monuments also displaying motifs of the Jugendstil were built in 1909 (and later?) from the terracotta elements of the Zsolnay Factory of Pécs. The mausoleum of the Nagy family who played an important role in the life of the city is still privately owned. The other one underwent a strange metamorphosis in 1963, as it was not redeemed again. The party committee of the city decided to convert it into a labour movement pantheon, and had the cross surrounded by palm branches in the pediment replaced by the red star. (The classicist character suited the socialist realist ideal of the fifties.) Their conservation in their current form is justified.

PRAKFALVI Endre művészettörténész. Miniszterelnökség, Örökségvédelmi Hatósági Főosztály, Örökségvédelmi Nyilvántartási Osztály / art historian, Cabinet office of the prime minister, Chief Department of National Heritage Protection Authorities, Department of National Heritage Registration

Kulcsszavak: sírkápolna, Ybl Miklós, Ágoston József, Brüll-mauzóleum, szecesszió, Gerster Kálmán, Stróbl Alajos, Hollán Ernő, historizmus, Lechner Ödön, Zsolnay Gyár, téglagyártás, Szentkirályi Nagy család, munkásmozgalmi panteon, szocreál / Keywords: sepulchral chapel, Miklós Ybl, József Ágoston, Brüll mausoleum, Jugendstil, Kálmán Gerster, Alajos Stróbl, Ernő Hollán, historism, Ödön Lechner, Zsolnay factory, brick-making, Szentkirályi Nagy family, labour movement pantheon, socialist realism 